\title{
Crystal Structure of $W_{1-x} B_{3}$ and Phase Equilibria in the Boron-Rich Part of the Systems Mo-Rh-B and $\mathrm{W}-\{\mathrm{Ru}, \mathrm{Os}, \mathrm{Rh}, \mathrm{Ir}, \mathrm{Ni}, \mathrm{Pd}, \mathrm{Pt}\}-\mathrm{B}$
}

\author{
I. Zeiringer, P. Rogl, A. Grytsiv, J. Polt, E. Bauer, and G. Giester
}

\author{
(Submitted December 19, 2013; in revised form February 5, 2014; published online March 13, 2014)
}

\begin{abstract}
The crystal structure of $W_{1-x} B_{3}$ has been reinvestigated by $x$-ray single crystal diffraction and revealed isotypism with the $M_{1-x} B_{3}$ structure type (space group $P_{3} / m m c ; a=0.52012(1)$, $\left.c=0.63315(3) \mathrm{nm} ; R_{\mathrm{F}}=0.040\right)$. As a characteristic feature of the structure, planar hexagonal metal layers (1/3 of atoms removed from ordered positions) sandwich planar boron honeycomb layers. One of the two $W$-sites shows a random defect of about $73 \%$. Strong metal boron and boron-boron bonds are responsible for high mechanical stability. Although $W_{1-x} B_{3}$ at about 80 at. $\%$ B is the metal boride richest in boron, it contains no directly linked three-dimensional boron framework. The solubility of $\mathrm{Rh}, \mathrm{Ir}, \mathrm{Ni}, \mathrm{Pd}$ and $\mathrm{Pt}$ in $\mathrm{W}_{1-x} \mathrm{~B}_{3}$ as well as of $\mathrm{Rh}$ in $\mathrm{Mo}_{1-x} \mathrm{~B}_{3}$ has been investigated in as cast state and after annealing. Furthermore, phase equilibria in the boron rich part of the corresponding isothermal sections $\mathrm{W}-\mathrm{TM}-\mathrm{B}\left(\mathrm{TM}=\mathrm{Rh}\right.$, Ir at $1100{ }^{\circ} \mathrm{C}$, $\mathrm{TM}=\mathrm{Ni}$, Pd at $900{ }^{\circ} \mathrm{C}$ and $\mathrm{TM}=\mathrm{Pt}$ at $800{ }^{\circ} \mathrm{C}$ ) and Mo-Rh-B (at $1100{ }^{\circ} \mathrm{C}$ ) have been established. A ternary compound only forms in the system W-Ir-B: $\tau_{1}-W_{1-x} I_{x} B_{2}$ with $\operatorname{ReB}_{2}$ structure type (space group $P 6_{3} / m m c ; a=0.2900, c=0.7475 \mathrm{~nm}$ ). The type of formation and crystal structure of diborides $\mathrm{W}_{1-x} T \mathrm{M}_{x} \mathrm{~B}_{2}\left(\mathrm{TM}=\mathrm{Ru}, \mathrm{Os}\right.$, Ir) isotypic with $\mathrm{ReB}_{2}$ were studied by $\mathrm{x}$-ray powder diffraction and electron probe microanalysis in as cast state and after annealing at $1500{ }^{\circ} \mathrm{C}$. Accordingly, $\mathrm{W}_{0.5} \mathrm{Os}_{0_{0.5}} \mathrm{~B}_{2}(a=0.29127(1), c=0.7562(1) \mathrm{nm})$ forms directly from the melt, whereas $W_{0.4} R u_{0.6} B_{2}(a=0.29027(1), c=0.74673(2) n m)$ and $W_{0.6} I_{0.4} B_{2}(a=0.29263(1)$, $c=0.75404(8) \mathrm{nm}$ ) are incongruently melting. Annealing at $1500{ }^{\circ} \mathrm{C}$ leads in case of the iridium compound to an almost single-phase product but the same procedure does not increase the amount of the ruthenium diboride.
\end{abstract}

Keywords crystal structure, isothermal section, ternary system, $x-$ ray structure analyses

\section{Introduction}

Superhard materials (i.e. a material with a hardness surmounting $40 \mathrm{GPa}^{[1-4]}$ ) are generally found in three different categories: (I) crystalline and disordered carbon modifications, (II) compounds formed by the light elements $\mathrm{B}, \mathrm{C}, \mathrm{N}, \mathrm{O}, \mathrm{Si}$ and (III) compounds of transition metals (TMs) with light elements $\mathrm{B}, \mathrm{C}, \mathrm{N}$ or $\mathrm{O} .^{[5,6]}$ The main important parameters guiding high hardness have been identified as (i) the presence of directional covalent bonding and (ii) a high electron concentration (electrons per atomic volume) of the transition metal (TM). ${ }^{[6,7]}$ Among borides

Dedicated in memoriam Prof. Dr. Fred Hayes.

I. Zeiringer, P. Rogl, A. Grytsiv, and J. Polt, Institute of Physical Chemistry, University of Vienna, Waehringerstr. 42, 1090 Wien, Austria; E. Bauer, Institute of Solid State Physics, Vienna University of Technology, Wiedner Hauptstr. 8-10, 1040 Wien, Austria; and G. Giester, Institute of Mineralogy and Crystallography, University of Vienna, Althanstr. 14, 1090 Wien, Austria. Contact e-mail: isolde. zeiringer@univie.ac.at and peter.franz.rogl@univie.ac.at. particularly those richest in boron in the systems with $\mathrm{W}$ ("WB $\mathrm{WB}_{4}$ at about 80 at.\% B) and $\operatorname{Re}\left(" \mathrm{ReB}_{2}\right.$ " at about 66.7 at.\% B) have triggered intensive research interest as potential superhard compounds. Although in many cases indentation hardness values beyond $40 \mathrm{GPa}$ have been measured at miniaturized loads, load independent hardness, which essentially characterizes the true hardness of a material, never surpassed the superhardness criterion of $40 \mathrm{GPa}$. In the following we list a few of these examples referring to transition metal borides. " $\mathrm{WB}_{4}$ " was reported to possess a load independent Vickers hardness of $31.8 \mathrm{GPa}$ (but $46.2 \mathrm{GPa}$ at $0.5 \mathrm{~N}){ }^{[6]}$ Load dependent hardness measurements and Re substitution studies by Mohammadi et al. ${ }^{[8]}$ yield a load independent hardness of $28.1 \mathrm{GPa}$ (but $43.3 \mathrm{GPa}$ at $0.5 \mathrm{~N}$ ) for $\mathrm{WB}_{4}$ and an increase to $32.5 \mathrm{GPa}$ $(49.8 \mathrm{GPa}(0.5 \mathrm{~N}))$ with an addition of about $1 \mathrm{~mol} \% \mathrm{Re}$. Polycrystalline $\mathrm{ReB}_{2}$ exceeds an average load independent Vickers hardness of about $30 \mathrm{GPa}(48 \mathrm{GPa}(0.5 \mathrm{~N}))^{[9]}$ or $26.6 \mathrm{GPa}(39.3 \mathrm{GPa}(0.5 \mathrm{~N}))^{[6]}$ with rather different hardness values obtained due to the anisotropic crystal structure. From Vickers hardness measurements on various crystallographic planes of a single crystal, Levine et al. ${ }^{[10]}$ determined the crystallographic (002) plane to be the hardest of $\mathrm{ReB}_{2}$. The isotypic substitution of Re by W/Os, W/Ir and $\mathrm{W} / \mathrm{Ru}$ has been studied first by Rogl and coworkers. ${ }^{[11,12]}$ Vickers hardness measurements on $\mathrm{W}_{0.5} \mathrm{Os}_{0.5} \mathrm{~B}_{2}$ revealed a load independent hardness of $26.6 \mathrm{GPa}$ (40.4 GPa 
$(0.5 \mathrm{~N}))^{[6]}$ and single crystal studies confirmed the $\mathrm{ReB}_{2}$ structure type with a random occupancy of the TM site. ${ }^{[2]}$ As the hardness of a material above the asymptotic leveling is not meaningful, ${ }^{[13,14]}$ all the aforementioned compounds cannot be considered as superhard materials but nevertheless are among the hardest metal borides.

Despite several structure models have been proposed in the past for the boron richest W-boride ${ }^{[15-19]} \mathrm{W}_{1-x} \mathrm{~B}_{3}$ ("WB 4 "), the structure type of isotypic $\mathrm{Mo}_{1-x} \mathrm{~B}_{3}{ }^{[19]}$ has been widely accepted. However, more recent theoretical calculations of band structure and physical properties (density functional theory calculations DFT) of this compound have inferred some confusion on the true crystal structure of " $\mathrm{WB}_{4}$ " ${ }^{[20-26]}$ Whereas the first studies by Chretien and Helgorsky ${ }^{[15]}$ reported a tetragonal unit cell for "WB $4 " ~(a=0.634 \mathrm{~nm}, c=0.450 \mathrm{~nm})$, Rudy et al. ${ }^{[16]}$ claimed a hexagonal cell $(a=0.3004 \mathrm{~nm}, c=0.3174 \mathrm{~nm})$ but proposed " $\mathrm{WB}_{12}$ " as a more appropriate composition. A first structure model was derived by Romans and Krug ${ }^{[17]}$ from x-ray powder data backed by single crystal Laue and precession photographs indexed on a hexagonal lattice $(a=0.5200 \mathrm{~nm}, c=0.6340 \mathrm{~nm})$. The proposed structure of stoichiometric $\mathrm{WB}_{4}$ was derived from the $\mathrm{AlB}_{2}$ structure, by replacing one third of the metal atoms by pairs of boron atoms (dumbbells) linking the two-dimensional planar boron layers into a three-dimensional covalently bonded boron framework. ${ }^{[17]}$ The boron dumbbells are located just in the voids (two per unit cell) created by the metal atom missing in the planar hexagonal closed packed metal atom layers at $z=1 / 4,3 / 4$. Independently Nowotny et al. ${ }^{[18]}$ proposed a similar structure on the basis of $\mathrm{x}$-ray powder and rotating crystal data $(a=0.5206 \mathrm{~nm}, c=0.6335 \mathrm{~nm})$, where $\left[\mathrm{B}_{6}\right]$-octahedra replace one third of the metal atoms in the hexagonal metal layer creating a three-dimensional boron-skeleton at a composition of $\mathrm{W}_{2-x} \mathrm{~B}_{9} \quad(x=1 /$ $6 \equiv \mathrm{W}_{17} \mathrm{~B}_{83}$ in at.\%). Nowotny et al. ${ }^{[18]}$ also evaluated the relation among the different sets of unit cell dimensions (see Fig. 1).

From the x-ray powder spectra reported there is no doubt that the phases " $\mathrm{WB}_{4}$ " and " $\mathrm{W}_{2-x} \mathrm{~B}_{9}$ " of the various aforementioned research groups ${ }^{[15-18]}$ are all identical and secondly are isotypic with the homologous phases observed in the Mo-B system: " $\mathrm{MoB}_{4}$ " and " $\mathrm{Mo}_{2-\mathrm{x}} \mathrm{B}_{9}$ " [15-19] Nowotny et al. ${ }^{[18]}$ furthermore reported on a considerable solubility of Rh, Ni, Pd and $\mathrm{Pt}$ in $\mathrm{W}_{2-x} \mathrm{~B}_{9}$ and particularly the $\mathrm{PhD}$ work of Haschke ${ }^{[27]}$ indicated the existence of ternary compounds $(\mathrm{Mo}, \mathrm{Rh})_{2-x} \mathrm{~B}_{9}$ and $(\mathrm{W}, \mathrm{M})_{2-x} \mathrm{~B}_{9}$ $(\mathrm{M}=\mathrm{Rh}, \mathrm{Ni}, \mathrm{Pd}, \mathrm{Pt})$ at $900^{\circ} \mathrm{C}$.

Lundström and Rosenberg ${ }^{[19]}$ analyzed in detail the $\mathrm{x}$-ray powder pattern of the crystal structure of $\mathrm{Mo}_{1-x} \mathrm{~B}_{3}\left(x \sim 0.2 ; P 6_{3} /\right.$ $m m c, a=0.52026 \mathrm{~nm}, c=6.3489 \mathrm{~nm}$, B-rich) from which they derived defect close-packed metal layers sandwiched by planar boron honeycomb layers stacked along the $c$-direction. ${ }^{[19]}$ There are no direct B-B contacts between B-layers. The boron honeycomb layers in $z=0$ are planar ${ }^{[17,19]}$ or slightly puckered $;{ }^{[18]}$ a planar boron honeycomb layer also exists in the structures at $z=0.5^{[17,19]}$. Lundström and Rosenberg ${ }^{[19]}$ confirmed isotypism with the homologous $\mathrm{W}_{1-x} \mathrm{~B}_{3}$.

The theoretical DFT studies on the structural assignment and stability of $\mathrm{WB}_{4}$ or $\mathrm{MoB}_{4}\left(\mathrm{WB}_{3} \text { or } \mathrm{MoB}_{3}\right)^{[20-26]}$

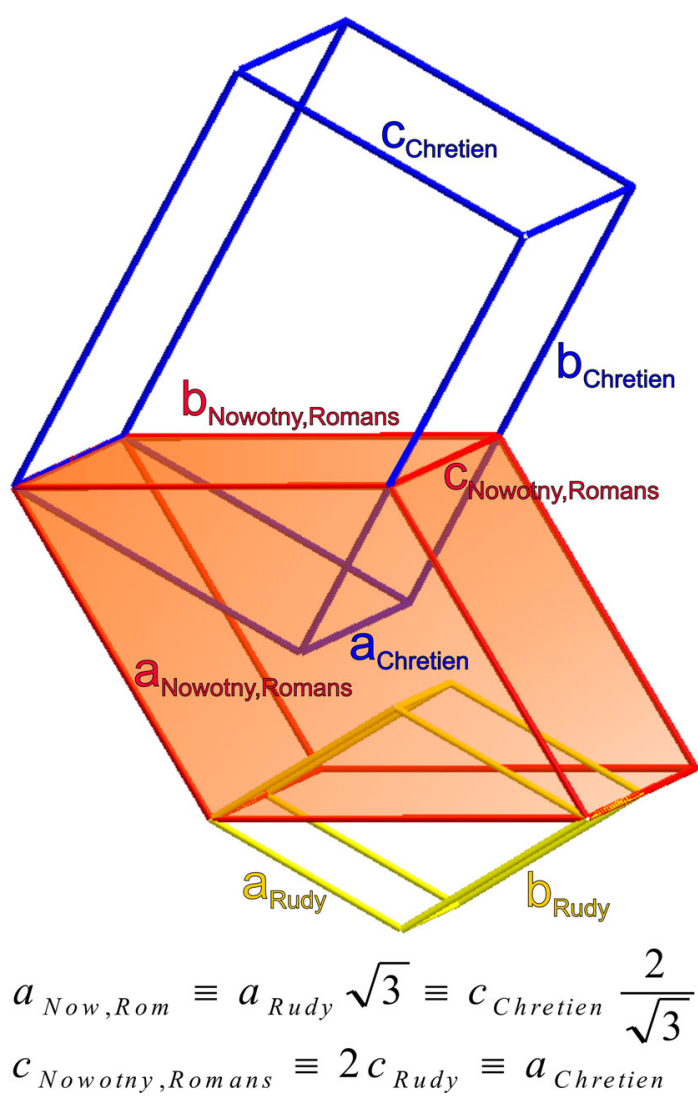

Fig. 1 Relation of the different unit cell propositions for "WB 4 " from Nowotny et al., ${ }^{[18]}$ Romans and Krug, ${ }^{[17]}$ Rudy et al. ${ }^{[16]}$ and Chretien et al. ${ }^{[15]}$

claimed that $\mathrm{WB}_{3}\left(\mathrm{MoB}_{3}\right)$ with a two-dimensional boron net is thermodynamically more stable than $\mathrm{WB}_{4}\left(\mathrm{MoB}_{4}\right)$ with a three-dimensional boron skeleton. ${ }^{[20-26]}$ Zhang et al. ${ }^{[24]}$ reopened the question on the correct crystal structure of $\mathrm{WB}_{4}$ or $\mathrm{WB}_{3}$, as the calculated indentation hardness of $\mathrm{WB}_{4}$ is lower than that of $\mathrm{ReB}_{2}$ in contrast to the experimental result and the calculated normalized $c / a$ ratio of $\mathrm{WB}_{3}$ exhibits a negative pressure dependence, inconsistent with the observed trend. Li et al. ${ }^{[25]}$ in their latest study presented new thermodynamically stable structures for $\mathrm{WB}_{3}(R \overline{3} m$ "6u") and $\mathrm{WB}_{4}\left(\mathrm{P6}_{3} / m m c\right.$-" $2 \mathrm{u}$ "). However, the DFT stability calculations so far never considered nonstoichiometric $\mathrm{W}_{1-\mathrm{x}} \mathrm{B}_{3}$ with defects in metal atom sites.

As most transition metal diborides exhibit superconductivity, Simonson et al. ${ }^{[28]}$ tested various transition metaldoped alloys $\mathrm{Mo}_{1-x} \mathrm{M}_{x} \mathrm{~B}_{4}(\mathrm{M}=\mathrm{Ti}, \mathrm{Zr}, \mathrm{Hf}, \mathrm{V}, \mathrm{Nb}, \mathrm{Ta}, \mathrm{Re})$ and the corresponding $\mathrm{W}_{1-x} \mathrm{M}_{x} \mathrm{~B}_{4}$ alloys. Indeed $\mathrm{Ti}$ and $\mathrm{Nb}$ doped $\mathrm{Mo}_{1-x} \mathrm{M}_{x} \mathrm{~B}_{4}$ alloys were claimed to reveal superconductivity below critical temperatures around $6.5 \mathrm{~K}(\mathrm{Ti})$ and $7.5 \mathrm{~K}(\mathrm{Nb})$, whereas no superconductivity has been detected in all the tungsten-based alloys.

In view of all these inconsistencies among experimental and DFT structural information, the tasks of the present work are (i) to elucidate the crystal structure of $\mathrm{W}_{1-x} \mathrm{~B}_{3}$ by single crystal $\mathrm{x}$-ray diffraction, (ii) to define the solubility of $\mathrm{Rh}, \mathrm{Ir}, \mathrm{Ni}, \mathrm{Pd}$ and $\mathrm{Pt}$ in $\mathrm{W}_{1-x} \mathrm{~B}_{3}$ as well as of $\mathrm{Rh}$ in $\mathrm{Mo}_{1-x} \mathrm{~B}_{3}$ 
(iii) to establish the phase equilibria in the boron rich part of the isothermal sections W-TM-B at $1100{ }^{\circ} \mathrm{C}(\mathrm{TM}=\mathrm{Rh}, \mathrm{Ir})$, at $900{ }^{\circ} \mathrm{C}(\mathrm{TM}=\mathrm{Ni}, \mathrm{Pd})$ and at $800{ }^{\circ} \mathrm{C}$ for $\mathrm{TM}=\mathrm{Pt}$ and of Mo-Rh-B at $1100{ }^{\circ} \mathrm{C}$ and (iv) to study formation and crystal structure of $\mathrm{ReB}_{2}$ isotypic compounds in the ternary systems $\mathrm{W}-\mathrm{TM}-\mathrm{B}(\mathrm{TM}=\mathrm{Ru}$, Os, Ir) and V-Ir-B in as cast state and at $1500{ }^{\circ} \mathrm{C}$.

\section{Experimantal Details}

Stoichiometric quantities of powders of vanadium, tungsten, molybdenum, iridium, rhodium (purity 99.99\%), nickel and crystalline boron (purity 98-99\%) were carefully mixed, cold-compacted to pellets and melted in an arc furnace under argon at least three times to ensure homogeneity. For the samples with Pd or Pt, metal ingots were used. The arc-melted buttons were cut into pieces, wherefrom one piece was wrapped in tantalum foil and vacuum-sealed in a quartz tube for annealing at 800,900 or $1100{ }^{\circ} \mathrm{C}$. The samples $\left(\mathrm{W}_{1-x} \mathrm{TM}_{x}\right) \mathrm{B}_{2}(\mathrm{TM}=\mathrm{Ru}, \mathrm{Os}, \mathrm{Ir})$ and $\mathrm{V}_{17} \mathrm{Ir}_{16} \mathrm{~B}_{67}$ were annealed at $1500{ }^{\circ} \mathrm{C}$ for $48 \mathrm{~h}$ on a BN-substrate in a high vacuum furnace of $3 \times 10^{-4} \mathrm{~Pa}$ with a W-sheet metal heater. All samples were characterized in as cast state and after annealing by scanning electron microscopy (SEM), electron probe microanalysis (EPMA) on a Zeiss Supra 55 VP operated at $20 \mathrm{kV}$ and $60 \mu \mathrm{A}$ using EDX and WDX detection for the quantitative analysis) and X-ray powder diffraction (XPD, Guinier-Huber image plate recording system, $\mathrm{Cu}-\mathrm{K} \alpha_{1}$ radiation). X-ray single crystal diffraction data (XSCD) were collected on a four-circle Nonius Kappa diffractometer with $\mathrm{C}$-monochromated $\mathrm{Mo}-\mathrm{K} \alpha$ radiation. The DSC measurements have been carried out on the annealed samples in a Netzsch 404 Pegasus DSC equipment under a stream of $6 \mathrm{~N}$ argon and heating rates of $5 \mathrm{~K} / \mathrm{min}$. The equipment was calibrated in the temperature range from 300 to $1400{ }^{\circ} \mathrm{C}$ against pure standard metals supplied by Netzsch to be within $\pm 1{ }^{\circ} \mathrm{C}$.

Further details of the characterization techniques can be found in our previous paper. ${ }^{[2]}$

\section{Results and Discussion}

\subsection{The Crystal Structure of $W_{1-x} B_{3}$}

As described in the introduction the compound $\mathrm{W}_{1-x} \mathrm{~B}_{3}$ (or $\mathrm{WB}_{4}$ ) is already known since the early 1960 s, its correct crystal structure, however, seems to be still under debate, because the established isotypism of $\mathrm{W}_{1-x} \mathrm{~B}_{3}{ }^{[15-18]}$ with the structure type of $\mathrm{Mo}_{1-x} \mathrm{~B}_{3}{ }^{[19]}$ has been ignored in more recent studies. ${ }^{[20-26]}$ As boron is difficult to detect by x-rays beside such a heavy metal element, several propositions have been made concerning the arrangement of the boron atoms in the crystal structure. Table 1 presents a listing of the crystallographic parameters for the three different structural models reported in the literature, which have been established for $\mathrm{WB}_{4},{ }^{[17]} \mathrm{W}_{2-x} \mathrm{~B}_{9}{ }^{[18]}$ and for $\mathrm{Mo}_{1-x} \mathrm{~B}_{3} .{ }^{[19]}$ At the bottom of Table 1 one can compare these structure models in three-dimensional view. All structure models agree on planar hexagonal metal layers from which $1 / 3$ of the atoms is removed. However, a (additional) significant metal atom defect in the crystallographic site $(0,0,0.25)$ was only described for $\mathrm{W}_{2-\mathrm{x}} \mathrm{B}_{9}$ $\left(\equiv \mathrm{W}_{1.83} \mathrm{~B}_{9}\right)^{[18]}$ and for $\mathrm{Mo}_{1-x} \mathrm{~B}_{3}\left(\equiv \mathrm{Mo}_{0.80} \mathrm{~B}_{3}\right){ }^{\left[{ }^{[19]}\right.}$

To reinvestigate the crystal structure, a single crystal has been selected from the crushed arc-melted sample with nominal composition $\mathrm{WB}_{9}$. The observed extinctions are consistent with the space groups $P 6_{3} m c, P \overline{6} 2 c$ or $P 6_{3} / m m c$. The crystal structure has been solved employing direct methods (using SHELX ${ }^{[30]}$ in the program OSCAIL ${ }^{[31]}$ ) in the hexagonal space group with highest symmetry $\mathrm{Pb}_{3} / \mathrm{mmc}$ (Nr.194; $a=0.52012(1), c=0.63315(3) \mathrm{nm})$. Although direct methods prompt the crystallographic sites $2 \mathrm{c}(1 / 3$, $2 / 3,1 / 4)$ and $2 b(0,0,1 / 4)$ for the heavy scatterers i.e. the $\mathrm{W}$ atoms, the Fourier series undoubtedly reveals a reduced occupancy for the latter site (2b) of only about $72 \%$ (see Table 2). The metal defects in $2 \mathrm{~b}$ appear randomly as there is no indication for a long-range metal/vacancy order. Boron atoms are located from the difference Fourier and occupy only the Wyckoff site $12 \mathrm{i}(x, 0,0)$ leading to the final composition $\mathrm{W}_{0.86} \mathrm{~B}_{3}$ ( $\equiv \mathrm{W}_{22} \mathrm{~B}_{78}$ in at.\%). Table 2 comprises the results of the single crystal refinement, which converged to a final R-factor $R_{\mathrm{F}}=0.040$ employing anisotropic atom displacement parameters for the $\mathrm{W}$-sites but isotropic temperature factors for the boron atom. The largest residual electron density and the deepest hole (6.62; $\left.-6.23 \mathrm{e} / \AA^{3}\right)$ are close $(\sim 0.4 \AA)$ to the tungsten atom in the $2 \mathrm{c}$ site and merely reflect the Fourier ripples to the large W-peak. It should be emphasized that the residual electron density reveals neither hints for $\mathrm{B}-\mathrm{B}$ dumbbells nor for $\mathrm{B}_{6}$ octahedra as proposed earlier in Ref $[17,19]$. Wyckoff sequence and atom positions in $\mathrm{W}_{0.86} \mathrm{~B}_{3}$ confirm isotypism with the structure model presented by Lundström and Rosenberg for $\mathrm{Mo}_{1-x} \mathrm{~B}_{3}$. A three-dimensional view on the crystal structure of $\mathrm{W}_{1-x} \mathrm{~B}_{3}$ is shown in Fig. 2, which also presents the coordination polyhedra for all atom sites. The structure solution obtained from the single crystal data fits well with the XPD data as can be seen from the Rietveld refinement (using the FULLPROF program ${ }^{[32]}$ ) in the right part of Fig. 2. The interatomic bonding distances in Table 2 merely reflect strong metal-boron bonding in the coordination figures as $d_{\mathrm{W}-\mathrm{B}}=0.235 \mathrm{~nm}$ is always smaller than the sum of the $\mathrm{W}$-metal $\left(R_{\mathrm{W}}=0.139 \mathrm{~nm}\right)$ and covalent B-radius $\left(R_{\mathrm{B}}=0.088 \mathrm{~nm}\right){ }^{[33]}$ The in-plane boron boron contacts $d_{\mathrm{B}-\mathrm{B}}=0.173 \mathrm{~nm}$ are fully consistent with the covalent radius sum, but $\mathrm{W}-\mathrm{W}$ contacts $d_{\mathrm{W}-\mathrm{W}}=0.300 \mathrm{~nm}$ are slightly larger than the sum of their metal atom radii. As seen from Fig. 1 the metal coordination around the B-atom is a truncated triangular tungsten prism of which only 4 next nearest neighbours remain in form of a rather distorted tetrahedron. The strong metal-boron and boron-boron bonds in the structure are responsible for the high mechanical stability i.e. the high hardness and the ultra-incompressibility discussed in the literature ${ }^{[20-26]}$ similar to the transition metal diborides. ${ }^{[34]}$ It should be mentioned that the two identical next nearest neighbour coordination figures around the two W-sites do not contain any hint for the defect in the W2 site-this may be explained in future DFT calculations. 
Table 1 Comparison of different structural models in standardized settings for $W_{B_{4}}$ or $W_{2-x} B_{9}$ and the isotypic compound $\mathrm{Mo}_{1-x} \mathrm{~B}_{3}$; only the B-B and metal-metal bonds are drawn in the unit cells

\begin{tabular}{|c|c|c|c|}
\hline & $\begin{array}{c}\text { Romans and } \mathrm{Krug}^{[17]} \\
\text { stoichiometric } \mathrm{WB}_{4}\end{array}$ & $\begin{array}{c}\text { Nowotny et al. }{ }^{[18]} ; \\
W_{2-x} B_{9}\left(x \sim 1 / 6 \equiv W_{0.61} B_{3}\right)\end{array}$ & $\begin{array}{l}\text { Lundström and Rosenberg }{ }^{[19]} ; \\
\operatorname{Mo}_{1-x} B_{3}\left(x \sim 0.2 \equiv \operatorname{Mo}_{0.80} B_{3}\right)\end{array}$ \\
\hline Space group & $P 6_{3} / m m c$ & $P \overline{3}$ & $\mathrm{PG}_{3} / m m c$ \\
\hline \multirow[t]{3}{*}{ Lattice parameter, nm } & $a=0.5200$ & $a=0.5026$ & $a=0.52026(2)$ \\
\hline & $c=0.6340$ & $c=0.6335$ & $c=0.63489(3)$ \\
\hline & & & B-rich \\
\hline$R_{\mathrm{I}}=\Sigma\left|I_{0}-I_{\mathrm{c}}\right| / \Sigma I_{0}$ & $\cdots$ & $\cdots$ & 0.088 \\
\hline \multicolumn{4}{|l|}{ Atomic parameter } \\
\hline M1/Wycoff Pos.; Occ & $\mathrm{W} 1$ in $2 \mathrm{c}(1 / 3,2 / 3,1 / 4) ; 1$ & $\mathrm{~W} 1$ in $2 \mathrm{~d}(1 / 3,2 / 3,0.250) ; 1$ & Mo1 in $2 \mathrm{c}(1 / 3,2 / 3,1 / 4) ; 1$ \\
\hline M2/Wycoff Pos.; Occ & $\mathrm{W} 2$ in $2 \mathrm{~b}(0,0,1 / 4) ; 1$ & $\mathrm{~W} 2$ in $2 \mathrm{c}(0,0,0.250) ; \sim 0.83$ & $\mathrm{Mo} 2$ in $2 \mathrm{~b}(0,0,1 / 4) ; 0.60(4)$ \\
\hline B1/Wycoff Pos.; Occ & $12 \mathrm{i}(0.333,0,0) ; 1$ & $6 \mathrm{~g}(0.0,0.333,0.023) ; 1$ & $12 \mathrm{i}(0.333,0,0) ; 1$ \\
\hline B2/Wycoff Pos.; Occ & 4f $(1 / 3,2 / 3,0.615) ; 1$ (form a dumbbel) & $6 \mathrm{~g}(0.472,0.331,0.202) ; 1$ & $\cdots$ \\
\hline B3/Wycoff Pos.; Occ & $\cdots$ & $6 \mathrm{~g}(0.475,0.141,0.427) ; 1$ & $\cdots$ \\
\hline Unit cell & & & \\
\hline
\end{tabular}

\subsection{Isothermal Sections of the Boron Rich Part of the Ternary Systems W-TM-B (TM = Rh, Ir, Ni, Pd, Pt) and Mo-Rh-B}

The isothermal sections $\{\mathrm{Mo}, \mathrm{W}\}-\mathrm{Rh}-\mathrm{B}$ at $1100{ }^{\circ} \mathrm{C}$, $\{\mathrm{Mo}, \mathrm{W}\}-\mathrm{Ni}-\mathrm{B}$ at $900{ }^{\circ} \mathrm{C},\{\mathrm{Mo}, \mathrm{W}\}-\mathrm{Pd}-\mathrm{B}$ at $950{ }^{\circ} \mathrm{C}$, and Mo-Pt-B at 900 and $800^{\circ} \mathrm{C}$ have been investigated by Haschke, ${ }^{[18,27]}$ whilst phase relations in the ternary system WIr-B at $1200{ }^{\circ} \mathrm{C}$ were published by Rogl et al. ${ }^{[35]}$ Haschke ${ }^{[27]}$ reported in all the aforementioned tungsten-based ternary systems and in the Mo-Rh-B system at the respective temperatures a ternary phase labeled as $\left\{\mathrm{W}(\mathrm{Mo})_{1-x} \mathrm{TM}_{x}\right\}_{2} \mathrm{~B}_{9}$ $(x \sim 0.33$ to 0.5$)$ with the structure type of " $\mathrm{W}_{2-x} \mathrm{~B}_{9}$ " ( $\equiv \mathrm{Mo}_{1-x} \mathrm{~B}_{3}$-type; see Fig. 3). Interestingly, the isothermal sections at these low temperatures neither contained the binary phase " $\mathrm{W}_{2-x} \mathrm{~B}_{9}$ " nor isotypic " $\mathrm{Mo}_{2-x} \mathrm{~B}_{9}$ ", thus reporting the compounds $\left\{\mathrm{W}(\mathrm{Mo})_{1-x} \mathrm{TM}_{x}\right\}_{2} \mathrm{~B}_{9}$ as truly ternary phases. As thermal instability at lower temperatures was never reported for the binary borides richest in W or Mo (both at about 80 at.\% $\mathrm{B}$; for details see also $\operatorname{Ref}^{[36,37]}$ ), we decided to reinvestigate the boron rich part of these isotherms. Additionally, we studied the B-rich isothermal sections W-Ir-B and W-Pt-B at 1100 and $800{ }^{\circ} \mathrm{C}$, respectively. We also investigated the possible solid solutions starting from binary $(\mathrm{W}, \mathrm{Mo})_{1-x} \mathrm{~B}_{3}$ in as cast state and after annealing at 1100,900 or $800^{\circ} \mathrm{C}$ by XPD using Ge as a standard for the lattice parameter determination and EPMA. Crystallographic details of all appearing phases in the investigated regions are presented in Table 3 . Results are summarized in Table 4 together with the lattice parameters reported in the literature. As various formulae have been reported in the literature, we refer to the formula $\mathrm{W}_{1-x} \mathrm{~B}_{3}$ or $\mathrm{W}_{1-x} \mathrm{TM}_{x} \mathrm{~B}_{3}$ for an easier comparison in the column 'accepted composition' in Table 4. The 'accepted composition' for our alloys results from Rietveld refinement. We also investigated the solubility of $\mathrm{Rh}$ in $\mathrm{Mo}_{1-x} \mathrm{~B}_{3}$ in as cast state and after annealing at $1100{ }^{\circ} \mathrm{C}$. As a very accurate quantitative boron measurement is not possible by EPMA using EDX detection (see Table 4), we mainly focused in the samples with transition metals, on measuring the metal ratios. Information on the binary phase diagrams and phases for Mo-B, Rh-B, Ni-B and Pt-B is taken from Massalski, ${ }^{[38]}$ for W-B from Duschanek and Rogl ${ }^{[36]}$ and for Ir-B and Pd-B from Rogl. ${ }^{[39]}$ Particularly the binary solid solubilities of the various transition metals in $\beta$ rhombohedral boron in the temperature region from 900 to $1500{ }^{\circ} \mathrm{C}$ were taken from Crespo et al. ${ }^{[40]}$ as less than 0.25 at.\% for Mo and W (see also Rudy et al. ${ }^{[37]}$ ), and less than 0.1 at. $\%$ for $\mathrm{Ru}, \mathrm{Os}, \mathrm{Rh}$, Ir. For vanadium $(\sim 1.5$ at.\% V at $\left.1500{ }^{\circ} \mathrm{C}\right)$ and nickel $\left(\sim 2\right.$ at. $\% \mathrm{Ni}$ at $\left.900{ }^{\circ} \mathrm{C}\right)$ we follow the investigations of Garbouskas et al. ${ }^{[41]}$ and Smid et al., ${ }^{[42]}$ respectively. For all systems investigated, except for the W-Ir$\mathrm{B}$ system, a three-phase equilibrium exists between $\beta \mathrm{B}$, $\mathrm{W}_{1-x} \mathrm{~B}_{3}$ or $\mathrm{Mo}_{1-x} \mathrm{~B}_{3}$ and the transition metal boride richest in boron (RhB, NiB, $\mathrm{Pd}_{2} \mathrm{~B}, \mathrm{PtB}_{0,67}$, see Fig. 4). The peritectic formation of $\mathrm{W}_{1-x} \mathrm{~B}_{3}$ around grains of $\mathrm{WB}_{2}$ (labeled earlier as $\mathrm{W}_{2} \mathrm{~B}_{5-x}$-type) is documented in all tungsten-based alloys (see microstructures in Fig. 4). The last liquid crystallizes in form of a transition metal rich boride or eutectic. The same can be derived from the microstructure of the Mo-Rh-B alloy. In the boron rich part of the isothermal section of the W-Ir-B system, a three-phase equilibrium exists between $\mathrm{B}, \mathrm{WB}_{2}$ and $\tau_{1}$ $\mathrm{W}_{1-x} \mathrm{Ir}_{x} \mathrm{~B}_{2}\left(\mathrm{ReB}_{2}\right.$-type) and another between $\mathrm{B}, \mathrm{Ir}_{4} \mathrm{~B}_{5}$ and $\tau_{1}$ (see Fig. $4 \mathrm{c}$ ). The invariant reaction temperatures were measured for all systems with DSC and are summarized in Table 5 together with the results from EPMA measurements and x-ray phase analysis. The DSC data on ternary reaction 
Table 2 X-ray single crystal data for $\mathrm{W}_{1-x} \mathrm{~B}_{3}$ at RT, standardized with program Structure Tidy (MoK-radiation; $2^{\circ} \leq 2 \Theta \leq 70^{\circ} ; \omega$-scans, scan width $2^{\circ} ; 150$ s/frame); Anisotropic displacement parameters in, $\left(10^{-2} \mathrm{~nm}^{2}\right)$

Parameter/compound

Space group

Formula from refinement

$a, c, \mathrm{~nm}$

$\mu_{\mathrm{abs}}, \mathrm{mm}^{-1}$

$V, \mathrm{~nm}^{3}$

$\rho_{x}, \mathrm{~g} \mathrm{~cm}^{-3}$

Reflections in refinement

Number of variables

$R_{\mathrm{F}}=\Sigma\left|F_{0}-F_{\mathrm{c}}\right| \Sigma F_{0}$

$R_{\text {Int }}$

wR2

GOF

Extinction (Zachariasen)

Residual density $\mathrm{e}^{-} / \AA^{3}$; max; min

Atom parameters

$\mathrm{W} 1$ in $2 \mathrm{c}(1 / 3,2 / 3,1 / 4)$; occ

$U_{11}=U_{22}=U_{33}$

$\mathrm{W} 2$ in $2 \mathrm{~b}(0,0,1 / 4)$; occ

$U_{11}=U_{22}=U_{33}$

$\mathrm{B} 1$ in $12 \mathrm{i}(x, 0,0)$; occ.

$x$

$U_{\text {iso }}$

Interatomic distances, $\mathrm{nm}$ : standard deviation $<0.0001$

$\begin{array}{lll}\text { W1- } & 12 \mathrm{~B} 2 & 0.2346 \\ \text { W2- } & 12 \mathrm{~B} 2 & 0.2351 \\ \mathrm{~B} 1- & 1 \mathrm{~B} 1 & 0.1725 \\ & -2 \mathrm{~B} 1 & 0.1738 \\ & -2 \mathrm{~W} 1 & 0.2346 \\ & -2 \mathrm{~B} 2 & 0.2346 \\ & -2 \mathrm{~W} 2 & 0.2350\end{array}$

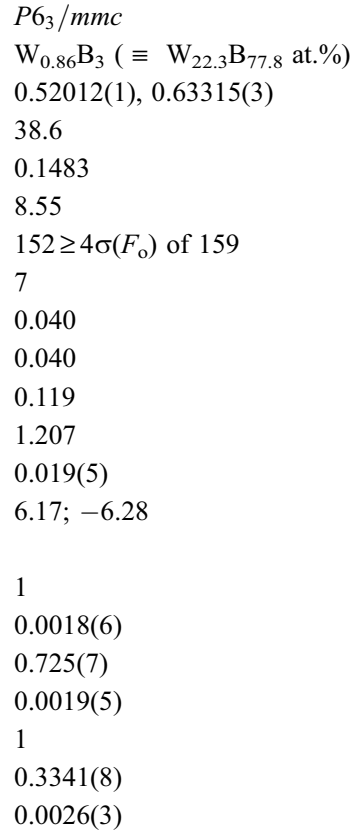

1738

2346
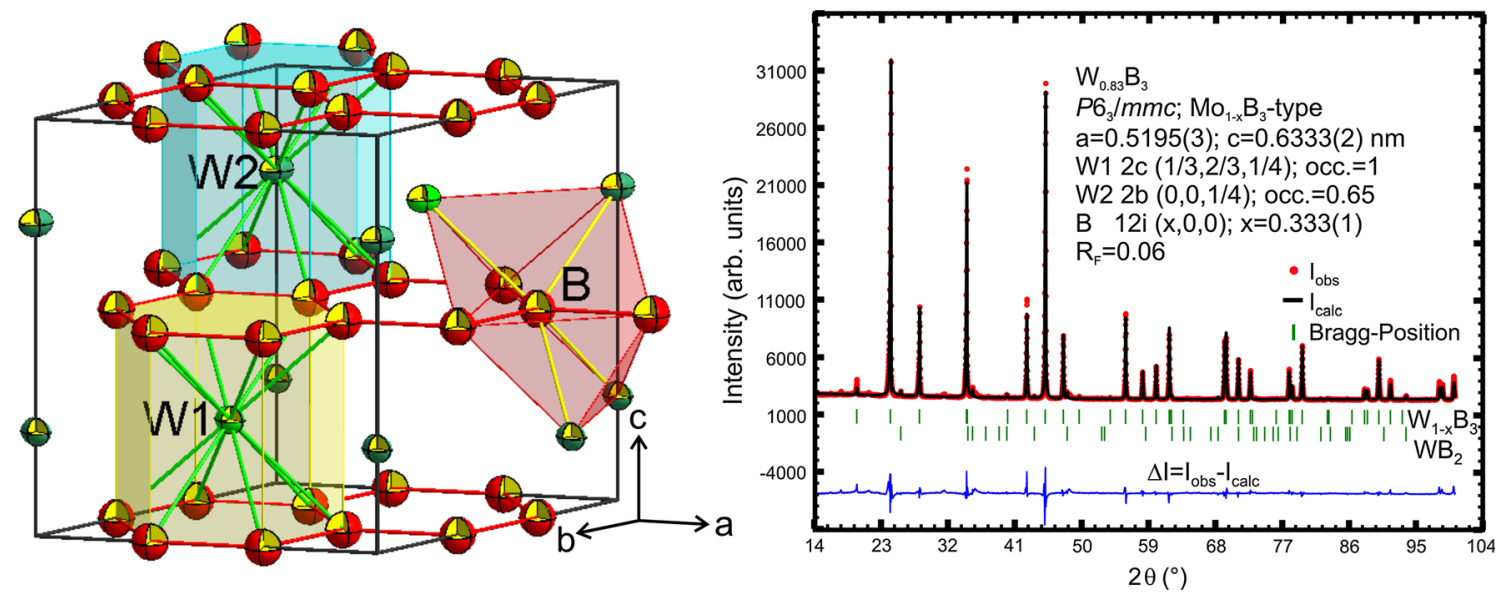

Fig. 2 Unit cell of $\mathrm{W}_{1-x} \mathrm{~B}_{3}$ including coordination polyhedra for all atoms and Rietveld refinement of the $\mathrm{x}$-ray powder pattern for $\mathrm{W}_{0.83} \mathrm{~B}_{3}$

isotherms in Table 5 demonstrate that on heating liquification temperatures in the ternary systems investigated are all close to or slightly below the binary boron-rich TM-B eutectic temperatures. Above these temperatures "burning" of alloys may appear even close to the high melting Mo-B and W-B binaries. 


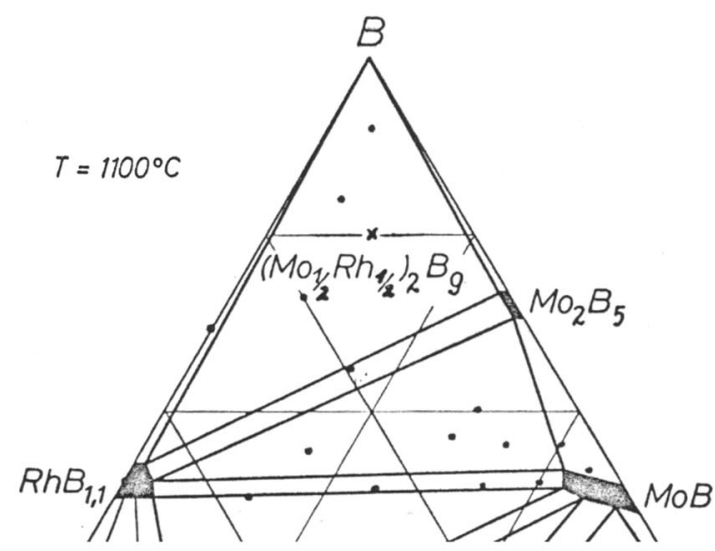

(a)

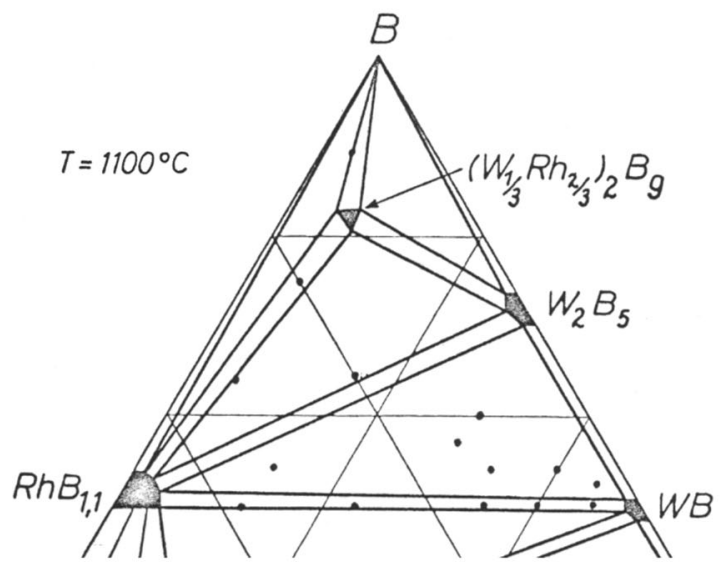

(c)

Fig. 3 Boron rich part of the isothermal sections of the ternary system $1100{ }^{\circ} \mathrm{C}$ and (d) W-Pd-B at $950{ }^{\circ} \mathrm{C}$; all as published by Haschke $\mathrm{e}^{[27]}$

As a result of our investigations, the phase equilibria in the boron-rich parts of the systems $\{\mathrm{Mo}, \mathrm{W}\}-\mathrm{Rh}-\mathrm{B}$, $\{\mathrm{Mo}, \mathrm{W}\}-\{\mathrm{Ni}, \mathrm{Pd}, \mathrm{Pt}\}-\mathrm{B}$ and $\mathrm{W}-\mathrm{Ir}-\mathrm{B}$, all reveal the existence of binary borides with the $\mathrm{Mo}_{1-x} \mathrm{~B}_{3}$-type (at about 80 at.\% B) without any extension (solid solubilities) into the corresponding ternaries. Accordingly there is practically no difference between the lattice parameters (within the error bars) of the binary $\mathrm{Mo}_{1-x} \mathrm{~B}_{3}$-type phases and those measured from ternary alloys (compare data in Tables 3 and 4). This argument also holds for a comparison of lattice parameters of the phases " $\left\{\mathrm{W}(\mathrm{Mo})_{1-x} \mathrm{TM}_{x}\right\}_{2} \mathrm{~B}_{9}$ " reported by Haschke $e^{[18,27]}$ with the binary $\mathrm{Mo}_{1-x} \mathrm{~B}_{3}$-type borides. Ternary compounds neither appeared in as cast condition nor in annealed alloys. The reason for the severe discrepancy between (i) the existence of ternary compounds $\left\{\mathrm{W}(\mathrm{Mo})_{1-x} \mathrm{TM}_{x}\right\}_{2} \mathrm{~B}_{9} \quad(x \sim 0.33$ to 0.5$)$ as reported by Haschke ${ }^{[27]}$ and (ii) the absence of ternary compounds but observation of isotypic phases in the binary with the structure type of " $\mathrm{W}_{2} \mathrm{~B}_{9}$ " ( $\equiv \mathrm{Mo}_{1-x} \mathrm{~B}_{3}$-type), may be found (a) in the slow reaction kinetics of the binary peritectically formed borides $\{\mathrm{Mo}, \mathrm{W}\}_{1-x} \mathrm{~B}_{3}$ as well as (b) in the significantly enhanced reaction kinetics concomitant with the severely lowered melting and liquidus temperatures (see DSC data in Table 5) in the ternary systems investigated.

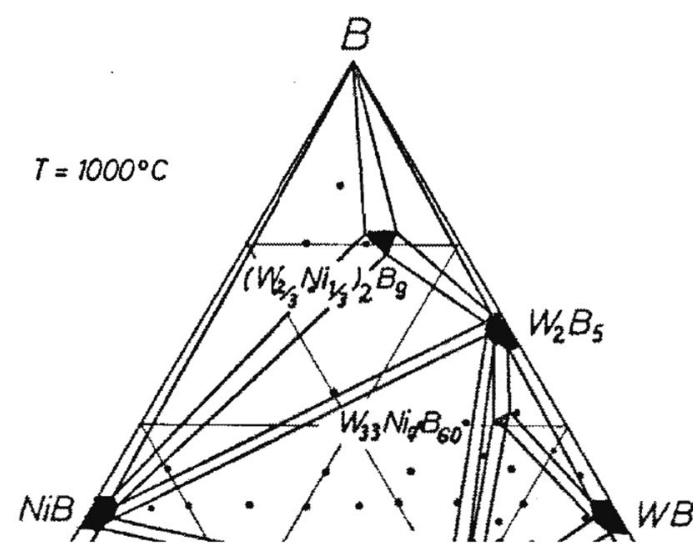

(b)

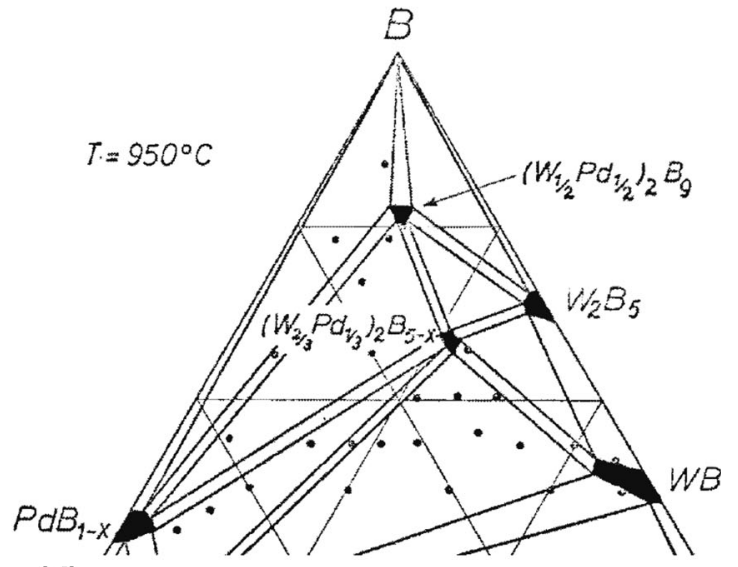

(d)

\subsection{The Tungsten-Based Ternary Transition Metal Diborides $W_{1-x} T M_{x} B_{2}(T M=R u, O s, I r)$}

Isotypic diborides with the structure type of $\mathrm{ReB}_{2}$ (space group $P 6_{3} / m m c ; a=0.2900, c=0.7475 \mathrm{~nm}^{[43]}$ ) can be achieved by combination of metal elements from the 6th $(\mathrm{Mo}, \mathrm{W})$ and 8 th $(\mathrm{Ru}, \mathrm{Os})$ group of the periodic table as they form a pseudo element from the 7th group. The electronegativity is approximately the same as for rhenium, if the metal ratio 6 th/8th is $\sim 1 / 2 .{ }^{[11,12]}$ More general, all isotypic compounds keep an electron/atom ratio between 4.3 and 4.4 ${ }^{[44]}$ f. e. $\mathrm{V}_{0.4} \mathrm{Os}_{0.6} \mathrm{~B}_{2},{ }^{[45]} \mathrm{W}_{0.5} \mathrm{Ir}_{0.4} \mathrm{~B}_{2}{ }^{[11,35]}$ and $\mathrm{Mo}_{x} \mathrm{Ir}_{1-x} \mathrm{~B}_{2}$ $(x=0.3,0.6){ }^{[12,40]}$ In this work, we investigated the type of formation and crystal structure of compounds with nominal composition $\mathrm{W}_{13} \mathrm{Ru}_{18} \mathrm{~B}_{69}, \mathrm{~W}_{15} \mathrm{Os}_{16} \mathrm{~B}_{69}, \mathrm{~W}_{18} \mathrm{Ir}_{13} \mathrm{~B}_{69}$ and $\mathrm{V}_{17} \mathrm{Ir}_{16} \mathrm{~B}_{67}$ in as cast state and after annealing at $1500{ }^{\circ} \mathrm{C}$ for 3 days. The compounds $\mathrm{W}_{0.4} \mathrm{Ru}_{0.6} \mathrm{~B}_{2}$ and $\mathrm{W}_{0.6} \mathrm{Ir}_{0.4} \mathrm{~B}_{2}$ (composition determined with EPMA, see Table 6) form incongruently (see Fig. 5a and c) whereas $\mathrm{W}_{0.5} \mathrm{Os}_{0.5} \mathrm{~B}_{2}$ forms directly from the melt (Fig. $5 b$ ). $W_{0.4} \mathrm{Ru}_{0.6} \mathrm{~B}_{2}$ forms in a peritectic reaction around large primary grains of $\mathrm{WB}_{2}$ $\left(\mathrm{W}_{2} \mathrm{~B}_{5-x}\right.$-type; Fig. 4a). However, annealing at $1500{ }^{\circ} \mathrm{C}$ does not change much the microstructure or composition of the appearing phases in the W-Ru-B system and therefore 
Table 3 Crystallographic data on the solid phases of the boron rich part of the ternary systems W-TM-B $(\mathrm{TM}=\mathrm{Rh}, \mathrm{Ir}, \mathrm{Ni}, \mathrm{Pd}, \mathrm{Pt})$ and Mo-Rh-B

\begin{tabular}{|c|c|c|c|c|c|c|}
\hline & & & & Lattice parameter, nm & & \\
\hline & Space group & Structure type & $a$ & $b$ & $c$ & Ref. \\
\hline (B) & $R \overline{3} m$ & $\beta B$ & $1.09382(5)$ & $\cdots$ & $2.38356(18)$ & [38] \\
\hline $\mathrm{WB}_{2}$ & $P 6_{3} / m m c$ & $\mathrm{WB}_{2}$ & $0.29831(1)$ & $\cdots$ & $1.38790(3)$ & [46] \\
\hline RT-MoB 2 & $R \overline{3} m$ & $\mathrm{MoB}_{2}$ & $0.30116(2)$ & $\cdots$ & $2.0937(2)$ & {$[50]$} \\
\hline HT-MoB 2 & $P 6 / \mathrm{mmm}$ & $\mathrm{AlB}_{2}$ & $0.30049(3)$ & $\cdots$ & $0.31726(4)$ & {$[50]$} \\
\hline $\mathrm{W}_{1-\mathrm{x}} \mathrm{B}_{3}$ & $P 6_{3} / m m c$ & $\mathrm{Mo}_{1-x} \mathrm{~B}_{3}$ & 0.5207 & $\ldots$ & 0.6303 & [18] \\
\hline $\mathrm{Mo}_{1-\mathrm{x}} \mathrm{B}_{3}$ & $P 6_{3} / m m c$ & $\mathrm{Mo}_{1-x} \mathrm{~B}_{3}$ & $0.52026(2)$ & $\cdots$ & $0.63489(3)$ & [19] \\
\hline $\mathrm{RhB}$ & $P 6_{3} / m m c$ & NiAs & 0.3309 & $\cdots$ & 0.4224 & [19] \\
\hline $\mathrm{Ir}_{4} \mathrm{~B}_{5}$ & $C 2 / m$ & $\mathrm{Ir}_{4} \mathrm{~B}_{5}$ & $1.05300(9)$ & $0.29038(3) \beta=91.119(9)^{\circ}$ & $0.61013(5)$ & [19] \\
\hline $\mathrm{NiB}$ & $\mathrm{Cmcm}$ & TII & 0.2929 & 0.7392 & 0.2961 & [19] \\
\hline $\mathrm{Pd}_{2} \mathrm{~B}$ & Pnnm & $\mathrm{CaCl}_{2}$ & $0.46918(4)$ & $0.51271(4)$ & $0.31096(3)$ & [19] \\
\hline $\mathrm{PtB}_{0.67}$ & $\mathrm{Cmcm}$ & $\mathrm{PtB}_{0.67}$ & $0.3371(1)$ & $0.5817(2)$ & $0.4045(1)$ & [19] \\
\hline $\mathrm{W}_{0.52} \mathrm{Ir}_{0.38} \mathrm{~B}_{2}$ & $P 6_{3} / m m c$ & $\mathrm{ReB}_{2}$ & 0.2926 & $\ldots$ & 0.7559 & [12] \\
\hline $\mathrm{W}_{0.3} \mathrm{Ru}_{0.7} \mathrm{~B}_{2}$ & $\mathrm{PG}_{3} / \mathrm{mmc}$ & $\mathrm{ReB}_{2}$ & 0.2906 & $\ldots$ & 0.7452 & [12] \\
\hline $\mathrm{W}_{0.3} \mathrm{Os}_{0.7} \mathrm{~B}_{2}$ & $P 6_{3} / m m c$ & $\mathrm{ReB}_{2}$ & 0.2911 & $\ldots$ & 0.7497 & [11] \\
\hline $\mathrm{W}_{0.5} \mathrm{Os}_{0.5} \mathrm{~B}_{2}$ & $P 6_{3} / m m c$ & $\mathrm{ReB}_{2}$ & $0.29120(2)$ & $\ldots$ & $0.75681(7)$ & {$[6]$} \\
\hline $\mathrm{RuB}_{2}$ & Pmmn & $\mathrm{RuB}_{2}$ & $0.46443(3)$ & $0.28668(8)$ & $0.40449(4)$ & [47] \\
\hline $\mathrm{OsB}_{2}$ & Pmmn & $\mathrm{RuB}_{2}$ & 0.4684 & 0.2872 & 0.4076 & [48] \\
\hline $\mathrm{VB}_{2}$ & $P 6 / \mathrm{mmm}$ & $\mathrm{AlB}_{2}$ & $0.2998(2)$ & $\cdots$ & $0.3057(2)$ & [49] \\
\hline
\end{tabular}

Table 4 Results from EPMA and XPD including literature data for $W_{1-x} B_{3}, W_{1-x} T_{x} B_{3}$ and $M_{1-x} B_{3}$

\begin{tabular}{|c|c|c|c|c|c|c|c|c|}
\hline \multirow[b]{2}{*}{ Nominal composition } & \multicolumn{3}{|c|}{ ЕРМА, at.\% } & \multirow[b]{2}{*}{ Accepted composition(a) } & \multicolumn{2}{|c|}{ Lattice parameter, nm } & \multirow[b]{2}{*}{ Heat treatment } & \multirow[b]{2}{*}{ Ref. } \\
\hline & $\mathbf{W}$ & $\mathbf{T M}$ & B & & $a$ & $c$ & & \\
\hline \multirow[t]{2}{*}{$\mathrm{WB}_{9}$} & 17.2 & $\cdots$ & 82.8 & $\mathrm{~W}_{0.81} \mathrm{~B}_{3}$ & $0.51953(3)$ & $0.6333(2)$ & As cast & This work \\
\hline & & & & $\mathrm{W}_{0.86} \mathrm{~B}_{3}$ & $0.52012(1)$ & $0.63315(3) \mathrm{SC}$ & & \\
\hline $\mathrm{WB}_{4}$ & $\cdots$ & $\cdots$ & $\cdots$ & $\mathrm{W}_{0.75} \mathrm{~B}_{3}$ & 0.5200 & 0.6340 & As cast & {$[17]$} \\
\hline $\mathrm{W}_{1.83} \mathrm{~B}_{9}$ & $\cdots$ & $\cdots$ & $\cdots$ & $\mathrm{W}_{0.61} \mathrm{~B}_{3}$ & 0.5207 & 0.6303 & $1400^{\circ} \mathrm{C}$ & {$[18]$} \\
\hline $\mathrm{WB}_{4}$ & $\ldots$ & $\cdots$ & $\ldots$ & $\mathrm{W}_{0.75} \mathrm{~B}_{3}$ & $0.5195(2)$ & $0.6332(1)$ & $1300{ }^{\circ} \mathrm{C}$ & {$[6]$} \\
\hline \multirow[t]{2}{*}{$\mathrm{W}_{0.5} \mathrm{Rh}_{2} \mathrm{~B}_{7.5}$} & 16.4 & $\cdots$ & 83.6 & $\mathrm{~W}_{0.8} \mathrm{~B}_{3}$ & $0.51981(5)$ & $0.6331(1)$ & As cast & This work \\
\hline & 17.3 & 0.8 & 81.9 & $\mathrm{~W}_{0.82} \mathrm{~B}_{3}$ & $0.52006(8)$ & $0.6342(2)$ & $1100^{\circ} \mathrm{C}$ & \\
\hline$\left(\mathrm{W}_{1 / 3} \mathrm{Rh}_{2 / 3}\right)_{2} \mathrm{~B}_{9}$ & $\ldots$ & $\cdots$ & $\cdots$ & $\mathrm{W}_{0.22} \mathrm{Rh}_{0.44} \mathrm{~B}_{3}$ & 0.520 & 0.627 & $1100^{\circ} \mathrm{C}$ & {$[18,27]$} \\
\hline $\mathrm{W}_{0.8} \mathrm{Ir}_{2} \mathrm{~B}_{7.2}$ & 26.4 & $\cdots$ & 73.6 & $\mathrm{~W}_{0.8} \mathrm{~B}_{3}$ & $0.52001(3)$ & $0.63249(7)$ & As cast & This work \\
\hline \multirow[t]{2}{*}{$\mathrm{W}_{1} \mathrm{Ni}_{0.5} \mathrm{~B}_{8.5}$} & 23.0 & 0.8 & 76.2 & $\mathrm{~W}_{0.8} \mathrm{~B}_{3}$ & $0.51990(5)$ & $0.6334(2)$ & As cast & This work \\
\hline & 25.1 & 0.3 & 74.6 & $\mathrm{~W}_{0.83} \mathrm{~B}_{3}$ & $0.51979(5)$ & $0.63366(7)$ & $900{ }^{\circ} \mathrm{C}$ & \\
\hline$\left(\mathrm{W}_{2 / 3} \mathrm{Ni}_{1 / 3}\right)_{2} \mathrm{~B}_{9}$ & $\ldots$ & $\ldots$ & $\ldots$ & $\mathrm{W}_{0.44} \mathrm{Ni}_{0.22} \mathrm{~B}_{3}$ & 0.520 & 0.630 & $1000{ }^{\circ} \mathrm{C}$ & {$[18,27]$} \\
\hline \multirow[t]{2}{*}{$\mathrm{W}_{0.6} \mathrm{Pd}_{1.4} \mathrm{~B}_{8}$} & 19.2 & $\cdots$ & 80.8 & $\mathrm{~W}_{0.83} \mathrm{~B}_{3}$ & $0.51977(5)$ & $0.6334(1)$ & As cast & This work \\
\hline & 21.8 & 0.1 & 78.1 & $\mathrm{~W}_{0.85} \mathrm{~B}_{3}$ & $0.51962(6)$ & $0.6331(1)$ & $900{ }^{\circ} \mathrm{C}$ & \\
\hline$\left(\mathrm{W}_{1 / 2} \mathrm{Pd}_{1 / 2}\right)_{2} \mathrm{~B}_{9}$ & $\ldots$ & $\cdots$ & $\cdots$ & $\mathrm{W}_{0.33} \mathrm{Ni}_{0.33} \mathrm{~B}_{3}$ & 0.520 & 0.631 & $950{ }^{\circ} \mathrm{C}$ & {$[18,27]$} \\
\hline \multirow{2}{*}{$\mathrm{W}_{0.6} \mathrm{Pt}_{1.4} \mathrm{~B}_{8}$} & 23.8 & $\cdots$ & 76.2 & $\mathrm{~W}_{0.83} \mathrm{~B}_{3}$ & $0.51980(3)$ & $0.63302(7)$ & As cast & This work \\
\hline & 24.6 & $\ldots$ & 75.4 & $\mathrm{~W}_{0.83} \mathrm{~B}_{3}$ & $0.52006(2)$ & $0.6333(2)$ & $900{ }^{\circ} \mathrm{C}$ & \\
\hline$\left(\mathrm{W}_{2 / 3} \mathrm{Pt}_{1 / 3}\right)_{2} \mathrm{~B}_{9}$ & $\ldots$ & $\cdots$ & $\cdots$ & $\mathrm{W}_{0.44} \mathrm{Pt}_{0.22} \mathrm{~B}_{3}$ & 0.520 & 0.631 & $1050^{\circ} \mathrm{C}$ & {$[18,27]$} \\
\hline $\mathrm{Mo}_{1-x} \mathrm{~B}_{3}$ & $\ldots$ & $\ldots$ & $\ldots$ & $\mathrm{Mo}_{0.8} \mathrm{~B}_{3}$ & $0.52026(2)$ & $0.63489(3)$ & $1800^{\circ} \mathrm{C}$ & [19] \\
\hline $\mathrm{Mo}_{1-x} \mathrm{~B}_{3}$ & $\ldots$ & $\ldots$ & $\ldots$ & $\mathrm{Mo}_{0.91} \mathrm{~B}_{3}$ & $0.52646(6)$ & $0.6121(1)$ & $1400^{\circ} \mathrm{C}$ & {$[50]$} \\
\hline \multirow{2}{*}{$\mathrm{Mo}_{0.8} \mathrm{Rh}_{2} \mathrm{~B}_{7.2}$} & 18.0 & 0.1 & 81.9 & $\mathrm{Mo}_{0.82} \mathrm{~B}_{3}$ & $0.5209(2)$ & $0.6348(3)$ & As cast & This work \\
\hline & 19.6 & 0.6 & 79.8 & $\mathrm{Mo}_{0.8} \mathrm{~B}_{3}$ & $0.51902(5)$ & $0.6334(3)$ & $1100{ }^{\circ} \mathrm{C}$ & \\
\hline
\end{tabular}

$S C$ from single crystal

(a)From Rietveld refinement 

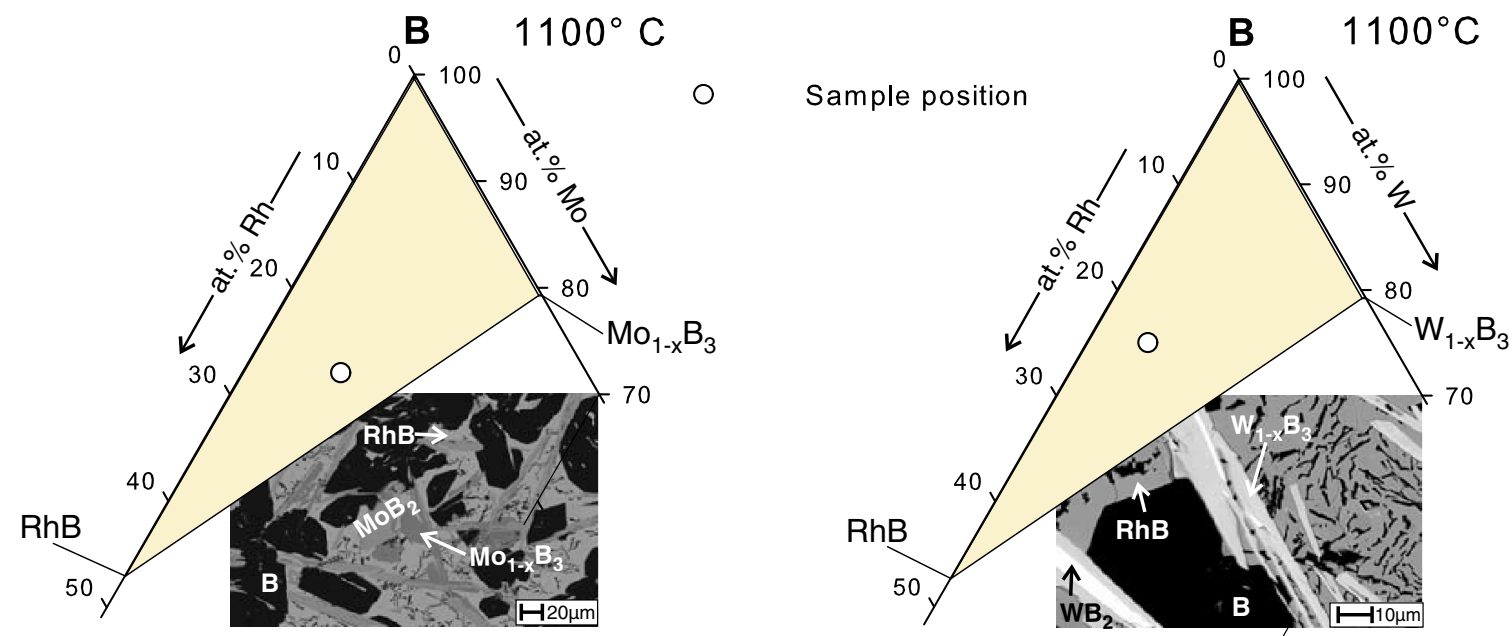

(a)
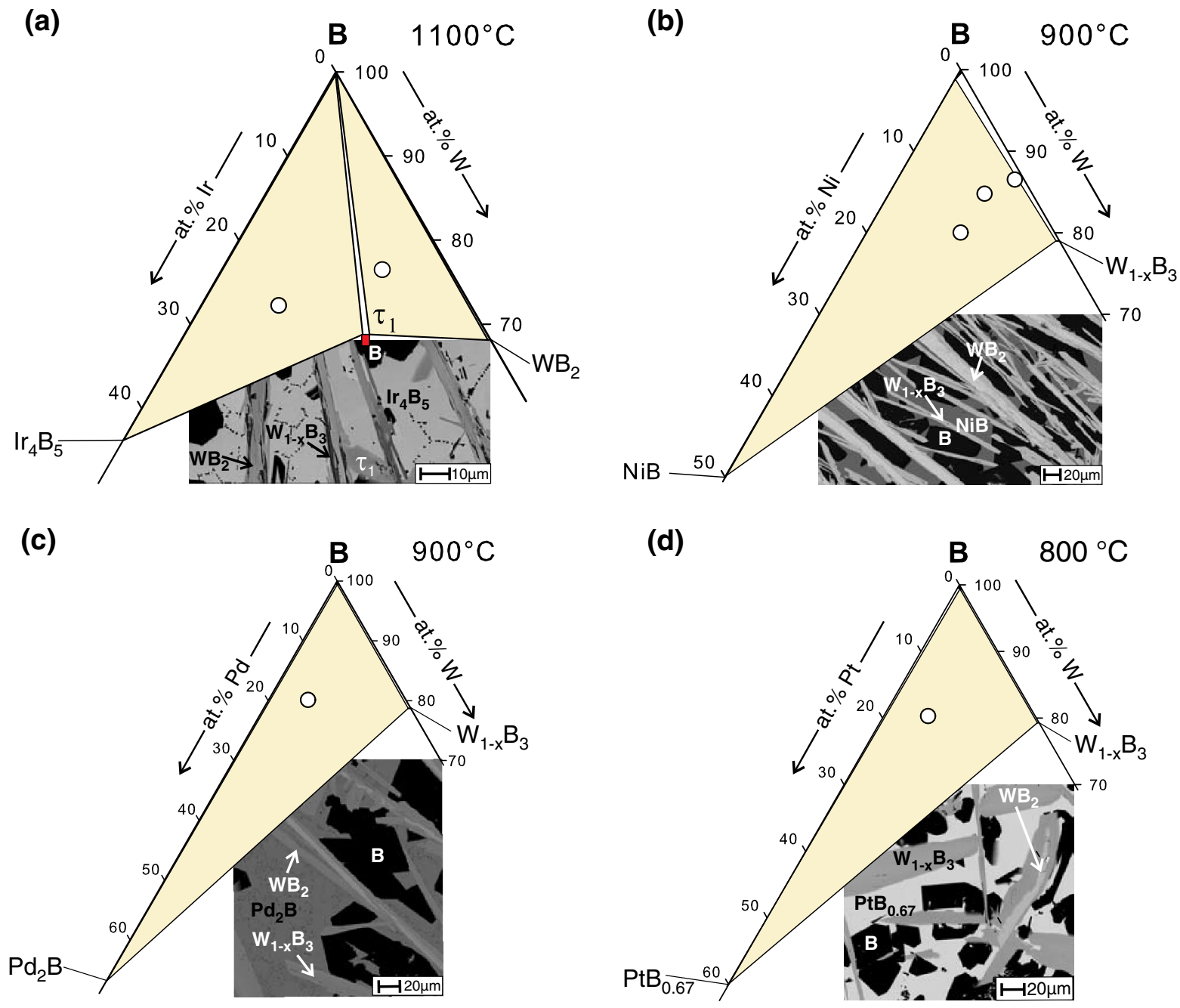

(e)

(f)

Fig. 4 Partial isothermal sections of the ternary systems (a) Mo-Rh-B and (b) W-Rh-B and (c) W-Ir-B at $1100{ }^{\circ} \mathrm{C}$ and of the ternary systems (d) W-Ni-B, (e) W-Pd-B at $900{ }^{\circ} \mathrm{C}$ and of (f) W-Pt-B at $800{ }^{\circ} \mathrm{C}$. The shown microstructures are from the alloys in as cast state 
Table 5 Results from EPMA measurements and x-ray phase analysis including invariant reaction temperatures from DTA measurements

\begin{tabular}{|c|c|c|c|c|c|c|c|c|c|}
\hline \multirow[b]{2}{*}{ Sample } & \multirow[b]{2}{*}{ Phases } & \multirow[b]{2}{*}{ Structure type } & \multicolumn{3}{|c|}{ Composition EPMA, at.\% } & \multirow[b]{2}{*}{ DTA $^{\circ} \mathrm{C}$} & \multicolumn{3}{|c|}{ Lattice parameter, nm } \\
\hline & & & Mo, W & $\mathbf{T M}$ & B & & $a$ & $b$ & $c$ \\
\hline $\mathrm{Mo}_{0.8} \mathrm{Rh}_{2} \mathrm{~B}_{7.2}$ & $\mathrm{~B}$ & B & 0.2 & 0.4 & 99.4 & 1115 & $\cdots$ & $\cdots$ & $\cdots$ \\
\hline \multirow[t]{2}{*}{1100} & $\mathrm{Mo}_{1-x} \mathrm{~B}_{3}$ & $\mathrm{Mo}_{1-x} \mathrm{~B}_{3}$ & 19.6 & 0.6 & 79.8 & & $0.51902(5)$ & $\cdots$ & $0.6334(3)$ \\
\hline & $\mathrm{RhB}$ & NiAs & 0.0 & 43.9 & 56.1 & & $0.3313(2)$ & $\cdots$ & $0.4218(2)$ \\
\hline $\mathrm{W}_{0.5} \mathrm{Rh}_{2} \mathrm{~B}_{7.5}$ & $\mathrm{~B}$ & B & 0.2 & 0.1 & 99.7 & 1115 & $\cdots$ & $\cdots$ & $\cdots$ \\
\hline \multirow[t]{2}{*}{1100} & $\mathrm{~W}_{1-x} \mathrm{~B}_{3}$ & $\mathrm{Mo}_{1-x} \mathrm{~B}_{3}$ & 17.3 & 0.8 & 81.9 & & $0.52006(8)$ & $\cdots$ & $0.6342(2)$ \\
\hline & RhB & $\mathrm{NiAs}$ & 0.0 & 43.2 & 56.8 & & $0.33233(1)$ & $\cdots$ & $0.42010(4)$ \\
\hline $\mathrm{W}_{0.8} \mathrm{Ir}_{2} \mathrm{~B}_{7.2}$ & $\mathrm{~B}$ & B & 0.5 & 0.2 & 99.3 & 1264 & $\cdots$ & $\cdots$ & $\cdots$ \\
\hline \multirow[t]{2}{*}{1100} & $\mathrm{Ir}_{4} \mathrm{~B}_{5}$ & $\mathrm{Ir}_{4} \mathrm{~B}_{5}$ & 0.0 & 43.3 & 56.7 & & $1.0535(4)$ & $0.2904(1) \beta=91.15(3)$ & $0.6103(1)$ \\
\hline & $\tau_{1}$ & $\mathrm{ReB}_{2}$ & 19.8 & 13.6 & $66.6^{\mathrm{a}}$ & & $0.29266(2)$ & $\cdots$ & $0.7538(1)$ \\
\hline $\mathrm{W}_{1.6} \mathrm{Ir}_{0.8} \mathrm{~B}_{7.6}$ & $\mathrm{~B}$ & B & 0.5 & 0.0 & 99.5 & $\cdots$ & $\cdots$ & $\cdots$ & $\cdots$ \\
\hline \multirow[t]{2}{*}{1100} & $\tau_{1}$ & $\mathrm{ReB}_{2}$ & 20.7 & 12.7 & $66.6^{\mathrm{a}}$ & & $0.29272(2)$ & $\cdots$ & $0.7535(1)$ \\
\hline & $\mathrm{WB}_{2}$ & $\mathrm{WB}_{2}$ & 32.8 & 0.0 & 67.2 & & $0.29855(2)$ & $\cdots$ & $1.3887(4)$ \\
\hline $\mathrm{WNi}_{0.5} \mathrm{~B}_{8.5}$ & $\mathrm{~B}$ & B & 0.3 & 1.4 & 98.3 & 1041 & $\cdots$ & $\cdots$ & $\cdots$ \\
\hline \multirow[t]{2}{*}{900} & $\mathrm{~W}_{1-x} \mathrm{~B}_{3}$ & $\mathrm{Mo}_{1-x} \mathrm{~B}_{3}$ & 25.1 & 0.3 & 74.6 & & $0.51979(5)$ & $\cdots$ & $0.63366(7)$ \\
\hline & $\mathrm{NiB}$ & TII & 0.1 & 50.6 & 49.3 & & $\cdots$ & $\cdots$ & $\cdots$ \\
\hline $\mathrm{W}_{0.6} \mathrm{Pd}_{1.4} \mathrm{~B}_{8}$ & B & B & 0.4 & 0.1 & 99.5 & 963 & $\cdots$ & $\cdots$ & $\cdots$ \\
\hline \multirow[t]{2}{*}{900} & $\mathrm{~W}_{1-x} \mathrm{~B}_{3}$ & $\mathrm{Mo}_{1-x} \mathrm{~B}_{3}$ & 21.8 & 0.1 & 78.1 & & $0.51962(6)$ & $\cdots$ & $0.6331(1)$ \\
\hline & $\mathrm{Pd}_{2} \mathrm{~B}$ & $\mathrm{CaCl}_{2}$ & 0.0 & 65.9 & 33.9 & & $0.4691(1)$ & $0.5135(2)$ & $0.3136(2)$ \\
\hline $\mathrm{W}_{0.6} \mathrm{Pt}_{1.4} \mathrm{~B}_{8}$ & $\mathrm{~B}$ & B & 0.4 & 0.0 & 99.6 & 777 & $\cdots$ & $\cdots$ & $\cdots$ \\
\hline \multirow[t]{2}{*}{800} & $\mathrm{~W}_{1-x} \mathrm{~B}_{3}$ & $\mathrm{Mo}_{1-x} \mathrm{~B}_{3}$ & 24.8 & 0.0 & 75.2 & & $0.52006(2)$ & $\cdots$ & $0.6333(2)$ \\
\hline & $\mathrm{PtB}_{0.67}$ & $\mathrm{PtB}_{0.67}$ & 0.3 & 59.1 & 40.6 & & $0.3372(1)$ & $0.5820(1)$ & 0.4031(1) \\
\hline
\end{tabular}

Table 6 Results from EPMA measurements and $x$-ray phase analysis for the alloys $W_{18} R_{13} B_{69}, W_{15} O s_{16} B_{69}$, $\mathrm{W}_{18} \operatorname{Ir}_{13} B_{69}$ and $V_{17} \operatorname{Ir}_{16} B_{67}$ in as cast state and/or after annealing at $1500{ }^{\circ} \mathrm{C}$

\begin{tabular}{|c|c|c|c|c|c|c|c|c|}
\hline \multirow[b]{2}{*}{ Sample } & \multirow[b]{2}{*}{ Phases } & \multirow[b]{2}{*}{ Structure type } & \multicolumn{3}{|c|}{ Composition EPMA, at.\% } & \multicolumn{3}{|c|}{ Lattice parameter, nm } \\
\hline & & & $\mathbf{W}, \mathbf{V}$ & $\mathbf{T M}$ & B & $a$ & $\boldsymbol{b}$ & $c$ \\
\hline $\mathrm{W}_{13} \mathrm{Ru}_{18} \mathrm{~B}_{69}$ & $\mathrm{~B}$ & B & $\cdots$ & 0.4 & 99.6 & $\cdots$ & $\cdots$ & $\cdots$ \\
\hline \multirow[t]{3}{*}{ as cast } & $\mathrm{WB}_{2}$ & $\mathrm{WB}_{2}$ & 30.6 & 1.7 & 67.7 & $0.29850(1)$ & $\cdots$ & $1.3866(5)$ \\
\hline & $\mathrm{RuB}_{2}$ & $\mathrm{RuB}_{2}$ & 1.1 & 35.9 & 63.0 & $0.28715(3)$ & $0.4641(1)$ & $0.40494(5)$ \\
\hline & $\mathrm{W}_{1-x} \mathrm{Ru}_{x} \mathrm{~B}_{2}$ & $\mathrm{ReB}_{2}$ & 12.3 & 21.1 & $66.6^{\mathrm{a}}$ & $0.29027(1)$ & $\cdots$ & $0.74673(2)$ \\
\hline $\mathrm{W}_{15} \mathrm{Os}_{16} \mathrm{~B}_{69}$ & $\mathrm{~B}$ & B & 0.1 & 0.9 & 99.0 & $\cdots$ & $\cdots$ & $\cdots$ \\
\hline \multirow[t]{2}{*}{1500} & $\mathrm{OsB}_{2}$ & $\mathrm{RuB}_{2}$ & 0.7 & 36.6 & 62.7 & $\cdots$ & $\cdots$ & $\cdots$ \\
\hline & $\mathrm{W}_{1-x} \mathrm{Os}_{x} \mathrm{~B}_{2}$ & $\mathrm{ReB}_{2}$ & 16.3 & 17.1 & $66.6^{\mathrm{a}}$ & $0.29127(1)$ & $\cdots$ & $0.7562(1)$ \\
\hline $\mathrm{W}_{18} \mathrm{Ir}_{13} \mathrm{~B}_{69}$ & $\mathrm{~B}$ & B & 0.4 & $\cdots$ & 99.6 & $\cdots$ & $\cdots$ & $\cdots$ \\
\hline \multirow[t]{4}{*}{ as cast } & $\mathrm{WB}_{2}$ & $\mathrm{WB}_{2}$ & 32.3 & 0.1 & 67.6 & $0.29864(1)$ & $\cdots$ & $1.3880(5)$ \\
\hline & $\mathrm{W}_{1-x} \mathrm{~B}_{3}$ & $\mathrm{Mo}_{1-x} \mathrm{~B}_{3}$ & 26.4 & $\cdots$ & 73.6 & $\cdots$ & $\cdots$ & $\cdots$ \\
\hline & $\mathrm{Ir}_{4} \mathrm{~B}_{5}$ & $\mathrm{Ir}_{4} \mathrm{~B}_{5}$ & $\cdots$ & 42.8 & 57.2 & $\cdots$ & $\cdots$ & $\cdots$ \\
\hline & $\mathrm{W}_{1-x} \mathrm{Ir}_{x} \mathrm{~B}_{2}$ & $\mathrm{ReB}_{2}$ & 17.8 & 15.6 & $66.6^{\mathrm{a}}$ & $0.29298(2)$ & $\cdots$ & $0.7539(1)$ \\
\hline $\mathrm{W}_{18} \mathrm{Ir}_{13} \mathrm{~B}_{69}$ & $\mathrm{~B}$ & B & 0.1 & 0.1 & 99.8 & $\cdots$ & $\cdots$ & $\cdots$ \\
\hline \multirow[t]{2}{*}{1500} & $\mathrm{Ir}_{4} \mathrm{~B}_{5}$ & $\mathrm{Ir}_{4} \mathrm{~B}_{5}$ & $\cdots$ & 42.6 & 57.4 & $\cdots$ & $\cdots$ & $\cdots$ \\
\hline & $\mathrm{W}_{1-x} \mathrm{Ir}_{x} \mathrm{~B}_{2}$ & $\mathrm{ReB}_{2}$ & 19.2 & 14.2 & $66.6^{\mathrm{a}}$ & $0.29263(1)$ & $\cdots$ & $0.75404(8)$ \\
\hline $\mathrm{V}_{17} \operatorname{Ir}_{16} \mathrm{~B}_{67}$ & $\mathrm{~B}$ & B & 1.6 & $\cdots$ & 98.4 & $\cdots$ & $\cdots$ & $\cdots$ \\
\hline \multirow[t]{2}{*}{1500} & $\mathrm{VB}_{2}$ & $\mathrm{AlB}_{2}$ & 26.7 & $\cdots$ & 73.3 & $0.2999(1)$ & $\cdots$ & $0.3056(1)$ \\
\hline & $\mathrm{Ir}_{4} \mathrm{~B}_{5}$ & $\mathrm{Ir}_{4} \mathrm{~B}_{5}$ & $\cdots$ & 44.2 & 55.8 & $1.0524(5)$ & $0.29042(2) \beta=91.12(4)$ & $0.6102(1)$ \\
\hline
\end{tabular}



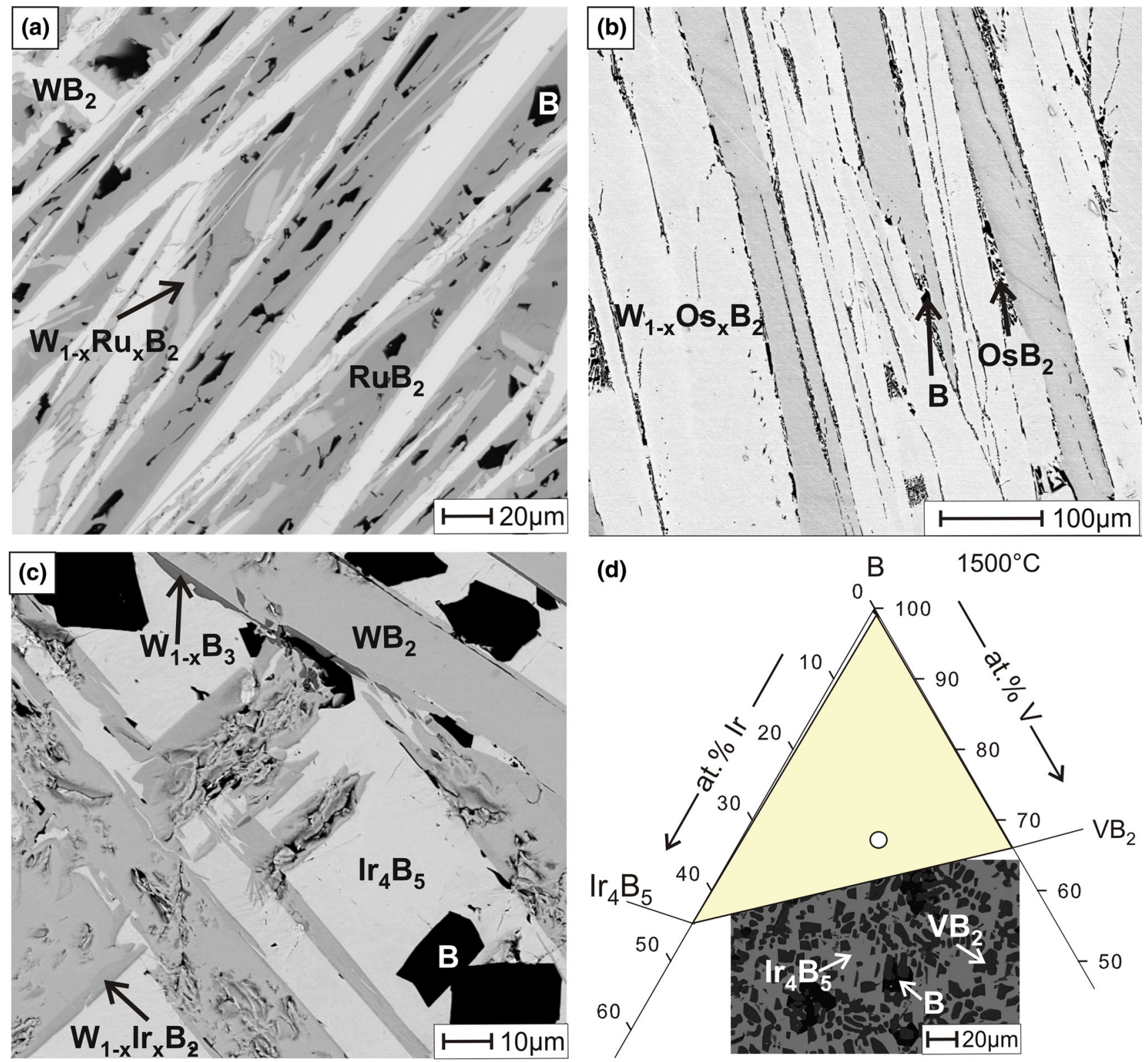

Fig. 5 SEM images of the alloys (a) $\mathrm{W}_{13} \mathrm{Ru}_{18} \mathrm{~B}_{69}$, (b) $\mathrm{W}_{15} \mathrm{Os}_{16} \mathrm{~B}_{69}$, (c) $\mathrm{W}_{18} \mathrm{Ir}_{13} \mathrm{~B}_{69}$ in as cast state and (d) partial isothermal section of the V-Ir-B phase diagram at $1500{ }^{\circ} \mathrm{C}$

these results are not included in Fig. 4 and Table 6. On the other hand, annealing of the carefully mixed and cold pressed powders (W, $\mathrm{Ru}$ and $\mathrm{B}$ ) at 900 to $1200{ }^{\circ} \mathrm{C}$ for $50 \mathrm{~h}$ in an argon atmosphere leads to homogeneous products. ${ }^{[12]}$ Therefore we suggest that probably the diffusion at $1500{ }^{\circ} \mathrm{C}$ is to slow due to a rather high liquidus temperature. In case of the $\mathrm{W}_{18} \mathrm{Ir}_{13} \mathrm{~B}_{69}$ sample, annealing at $1500{ }^{\circ} \mathrm{C}$ leads to an almost single-phase sample $\mathrm{W}_{0.6} \mathrm{Ir}_{0.4} \mathrm{~B}_{2}$ with only about $2 \%$ impurity phases $\left(\mathrm{Ir}_{4} \mathrm{~B}_{5}\right.$ and $\mathrm{B}$, see Table 6) but here even lower annealing temperatures $\left(\geq 1100{ }^{\circ} \mathrm{C}\right)$ are sufficient. $\mathrm{W}_{0.5} \mathrm{Os}_{0.5} \mathrm{~B}_{2}$ forms congruently and the SEM image in Fig. $4 \mathrm{~b}$ shows large grains and a three-phase eutectic at the grain boundaries consisting of $\mathrm{W}_{0.5} \mathrm{Os}_{0.5} \mathrm{~B}_{2}, \mathrm{OsB}_{2}$ and $\mathrm{B}$ (see Table 6, results for the annealed alloy). The $\mathrm{x}$-ray powder patterns of $\mathrm{W}_{15} \mathrm{Os}_{16} \mathrm{~B}_{69}$ in as cast state and after annealing contain sharp (h00, hk0) and rather diffuse and broad reflexions (001, h01). This has been observed already previously in some $\mathrm{x}$-ray powder diffractograms of $\mathrm{W}-\mathrm{Ru}-\mathrm{B}^{[12]}$ and MoOs- $\mathrm{B}^{[11]}$ alloys and has been explained by irregular stacking faults in the crystal structure in the $c$-direction. ${ }^{[12]}$ The possible formation of a $\mathrm{ReB}_{2}$ isotypic compound has also been tested for V-Ir-B but neither in as cast state or after annealing at $1500{ }^{\circ} \mathrm{C}$ any ternary compound appeared. At $1500{ }^{\circ} \mathrm{C}$, a three-phase equilibrium exists: $\mathrm{B}+\mathrm{VB}_{2}+\mathrm{Ir}_{4} \mathrm{~B}_{5}$ (see Fig. 5d and Table 6). 


\section{Conclusions}

The reinvestigation of the crystal structure of $\mathrm{W}_{1-x} \mathrm{~B}_{3}$ ( $\equiv \mathrm{WB}_{\sim 4}$ ) by $\mathrm{x}$-ray single crystal diffraction revealed isotypism with the $\mathrm{Mo}_{1-x} \mathrm{~B}_{3}$ structure type (space group $P 6_{3} / m m c$; $\left.a=0.52012(1), c=0.63315(3) \mathrm{nm} ; R_{\mathrm{F}}=0.040\right)$. Boron occupies only the crystallographic site $12 \mathrm{i}(x, 0,0)$ and tungsten the sites $2 \mathrm{c}(1 / 3,2 / 3,1 / 4)$ and $2 \mathrm{~b}(0,0,1 / 4)$, the latter being filled to only about $72 \%$. It should be emphasized that although $\mathrm{W}_{1-x} \mathrm{~B}_{3}$ at about 80 at. $\% \mathrm{~B}$ is the metal boride richest in boron, it shows no directly linked three-dimensional boron framework. No solubility of Rh, Ir, Ni, Pd and Pt in $\mathrm{W}_{1-x} \mathrm{~B}_{3}$ as well as of $\mathrm{Rh}$ in $\mathrm{Mo}_{1-\mathrm{x}} \mathrm{B}_{3}$ has been found in as cast state and after annealing by EPMA measurements and by comparing the lattice parameter with those of the binary alloys. Furthermore, the boron rich parts of the corresponding isothermal sections W-TM-B $\left(\mathrm{TM}=\mathrm{Rh}\right.$, Ir at $1100{ }^{\circ} \mathrm{C}, \mathrm{TM}=\mathrm{Ni}$, Pd at $900{ }^{\circ} \mathrm{C}$ and $\mathrm{TM}=\mathrm{Pt}$ at $800{ }^{\circ} \mathrm{C}$ ) and Mo-Rh-B (at $1100{ }^{\circ} \mathrm{C}$ ) have been established. Except for the W-Ir-B system, a three-phase equilibrium exists between $\beta$-boron, $\mathrm{W}_{1-x} \mathrm{~B}_{3}$ or $\mathrm{Mo}_{1-x} \mathrm{~B}_{3}$ and the transition metal boride richest in boron $\left(\mathrm{RhB}, \mathrm{NiB}, \mathrm{Pd}_{2} \mathrm{~B}\right.$, $\left.\mathrm{PtB}_{0,67}\right)$. In the W-Ir-B system, two three-phase euilibria exist in the investigated part. $\beta \mathrm{B}$ is in equilibrium with $\operatorname{Ir}_{4} \mathrm{~B}_{5}$ and $\tau_{1^{-}}$ $\mathrm{W}_{1-x} \mathrm{Ir}_{x} \mathrm{~B}_{2}\left(\mathrm{ReB}_{2}\right.$ type $)$ and with $\mathrm{WB}_{2}$ and $\tau_{1}$. Formation and crystal structure of diborides $\mathrm{W}_{1-x} \mathrm{TM}_{x} \mathrm{~B}_{2}(\mathrm{TM}=\mathrm{Ru}, \mathrm{Os}, \mathrm{Ir})$ with $\mathrm{ReB}_{2}$ structure type (space group $P 6_{3} / m m c ; a=0.2900$, $c=0.7475 \mathrm{~nm}$ ) were studied by XPD and EPMA in as cast state and after annealing at $1500{ }^{\circ} \mathrm{C} . \quad \mathrm{W}_{0.5} \mathrm{Os}_{0.5} \mathrm{~B}_{2}$ $(a=0.29127(1), c=0.7562(1) \mathrm{nm})$ forms directly from the melt, whereas $\mathrm{W}_{0.4} \mathrm{Ru}_{0.6} \mathrm{~B}_{2}(a=0.29027(1), c=0.74673$ (2) $\mathrm{nm}$ ) and $\mathrm{W}_{0.6} \mathrm{Ir}_{0.4} \mathrm{~B}_{2}(a=0.29263(1), c=0.75404(8) \mathrm{nm})$ are incongruently melting. Annealing at $1500{ }^{\circ} \mathrm{C}$ leads in case of the iridium compound to an almost single-phase product but the same procedure does not increase the amount of the ruthenium diboride.

\section{Acknowledgment}

This work was supported by the Austrian Science Fund FWF under Grant P22295. All EPMA measurements were carried out in the Faculty Centre for Nanostructure Research at the University of Vienna. Especially, we want to thank Dr. Puchegger for his help with the scanning electron microscope.

\section{References}

1. R. Riedel, Novel Ultrahard Materials, Adv. Mater., 1994, 6(7-8), p 549-560

2. S. Veprek, The Search for Novel Ultrahard Materials, J. Vac. Sci. Technol. A, 1999, 17(5), p 2401-2420

3. J. Haines, J.M. Leger, and G. Bocquillon, Synthesis and Design of Superhard Materials, Annu. Rev. Mater. Res., 2001, 31, p 1-23

4. A.L. Ivanovskii, The Search for Novel Superhard and Incompressible Materials on the Basis of Higher Borides of $s, p, d$ Metals, J. Superhard Mater., 2011, 33(2), p 73-87

5. V.V. Brazhkin, A.G. Lyapin, and R.J. Hemley, Harder Than Diamond: Dreams and Reality, Phil. Mag., 2002, 82, p 231-253
6. Q. Gu, G. Krauss, and W. Steurer, Transition Metal Borides: Superhard Versus Ultra Incompressible, Adv. Mater., 2008, 20, p 3620-3626

7. J.J. Gilman, R.W. Cumberland, and R.B. Kaner, Design of Hard Crystals, Int. J. Refract. Metals Hard Mater., 2006, 24(1-2), p 1-5

8. R. Mohammadi, A.T. Lech, M. Xie, B.E. Weaver, M.T. Yeung, S.H. Tolbert, and R.B. Kaner, Tungsten Tetraboride, An Inexpensive Superhard Material, PNAS, 2011, 108(27), p 10958-10962

9. H.Y. Chung, J.M. Yang, M.B. Weinberger, S.H. Tolbert, J.B. Levine, R.B. Kaner, and A. Kavner, Synthesis of UltraIncompressible Superhard Rhenium Diboride at Ambient Pressure, Science, 2007, 316(5823), p 436-439

10. J.B. Levine, S.L. Nguyen, S.E. Brown, H.I. Rasool, R.B. Kaner, and J.A. Wright, Preparation and Properties of Metallic, Superhard Rhenium Diboride Crystals, J. Am. Chem. Soc., 2008, 130, p 16953-16958

11. P. Rogl, H. Nowotny, and F. Benesovsky, Ternäre Komplexboride in den Dreistoffen: $\{\mathrm{Mo}, \mathrm{W}\}-\{\mathrm{Ru}, \mathrm{Os}\}-\mathrm{B}$ und W-Ir-B, Ternary Complex Borides in the Systems: $\{\mathrm{Mo}, \mathrm{W}\}-\{\mathrm{Ru}, \mathrm{Os}\}-\mathrm{B}$ and W-Ir-B, Monatsh. Chem., 1970, 101, p 850-854, in German

12. P. Rogl, H. Nowotny, and F. Benesovsky, Komplexboride mit $\mathrm{ReB}_{2}$ Struktur, Complex borides with $\mathrm{ReB}_{2}$ structure, Monatsh. Chem., 1970, 101, 27-31, in German

13. V. Brazhkin, N. Dubrovinskaia, M. Nicol, N. Novikov, R. Riedel, V. Solozhenko, and Y. Zhao, What Does 'Harder Than Diamond' Mean?, Nat. Mater., 2004, 3, p 576-577

14. N. Dubrovinskaia, L. Dubrovinsky, and V.L. Solozhenko, Comment on 'Synthesis of Ultra-Incompressible Superhard Rhenium Diboride at Ambient Pressure', Science, 2007, 318, p $1550 \mathrm{c}$

15. A. Chretien and J. Helgorsky, Sur les borures de molybdene et de tungstene $\mathrm{MoB}_{4}$ et $\mathrm{WB}_{4}$ composes nouveaux, Compt. Rend. Hebd. Seances Acad. Sci. Colon. (Paris), 1961, 252(5), p 742-744, in French

16. E. Rudy, F. Benesovsky, and L. Toth, The Investigation of the Ternary Systems of the Group V and VI, Metals with Boron and Carbon, Z. Metallkd., 1963, 54, p 345-353, in German

17. P.A. Romans and M.P. Krug, Composition and Crystallographic Data for the Highest Boride of Tungsten, Acta Crystallogr., 1966, 20, p 313-315

18. H. Nowotny, H. Haschke, and F. Benesovsky, Bor-reiche Wolframboride, Boron Rich Tungsten Borides, Monatsh. Chem., 1967, 98, p 547-554, in German

19. T. Lundström and I. Rosenberg, The Crystal Structure of the Molybdenum Boride $\mathrm{Mo}_{1-x} \mathrm{~B}_{3}$, J. Solid State Chem., 1973, 6 , p 299-305

20. Y. Liang, X. Yuan, and W. Zhang, Thermodynamic Identification of Tungsten Borides, Phys. Rev. B, 2001, 83, p 220102(R)

21. H. Gou, Z. Li, L.M. Wang, J. Lian, and Y. Wang, Peculiar Structure and Tensile Strength of $\mathrm{WB}_{4}$ : Nonstoichiometric Origin, AIP Adv., 2012, 2, p 012171

22. Y. Liang, Z. Fu, X. Yuan, S. Wang, Z. Zhong, and W. Zhang, An unexpected softening from $\mathrm{WB}_{3}$ to $\mathrm{WB}_{4}$, EPL, 2012, 98(6), 66004

23. R.F. Zhang, D. Legut, Z.J. Lin, Y.S. Zhao, H.K. Mao, and S. Veprek, Stability and Strength of Transition-Metal Tetraborides and Triborides, $P R L, 2012, \mathbf{1 0 8}, \mathrm{p} 255502$

24. C. Zang, H. Sun, and C. Chen, Unexpectedly Low Indentation Strength of $\mathrm{WB}_{3}$ and $\mathrm{MoB}_{3}$ from First Principles, Phys. Rev. $B, 2012,86$, p 180101(R)

25. Q. Li, D. Zhou, W. Zheng, and Y. Ma, Global Structural Optimization of Tungsten Borides, PRL, 2013, 110, p 136403 
26. Y. Liang, X. Yuan, Z. Fu, Y. Li, and Z. Zhong, An Unusual Variation of Stability and Hardness in Molybdenum Borides, Appl. Phys. Lett., 2012, 101, p 181908

27. H. Haschke, Structural Chemical Investigations on Complex Borides and Carbides, as Well as on Silicides and Germanides of Rare Earth Metals PhD-Thesis, 1966, University of Vienna, in German

28. J.W. Simonson, D. Wu, S.J. Poon, and S.A. Wolf, Superconductivity in Transition Metal Doped $\mathrm{MoB}_{4}$, J. Supercond. Nov. Magn., 2010, 23, p 417-422

29. N. Melnychenko-Koblyuk, A. Grytsiv, S. Berger, H. Kaldarar, H. Michor, F. Rohrbacher, E. Royanian, P. Rogl, H. Schmid, and G. Giester, Ternary Clathrates Ba-Cd-Ge: Phase Equilibria, Crystal Chemistry and Physical Properties, J. Phys. Condens. Matter, 2007, 19, p 046203

30. G.M. Sheldrick, SHELX-Program, Acta Cryst. A, 2008, 64, p $112-122$

31. P. McArdle, K. Gilligan, D. Cunningham, R. Dark, and M. Mahon, Oscail-Program, Cryst. Eng. Commun., 2004, 6, p 303-309

32. J. Rodriguez-Carvajal, Recent Advances in Magnetic Structure Determination by Neutron Diffraction, Physica B, 1993, 192, p $55-69$

33. W.B. Pearson (1972), The Crystal Chemistry and Physics of Metals and Alloys, New York, USA: Wiley-Interscience, The 12-coordinated metallic radii in Table 4-4 of this book have been taken from: E. Teatum, K. Gschneidner, and J. Waber, Report LA-2345, US Department of Commerce, Washington, D.C., USA, 1960

34. X.-Q. Chen, C.L. Fu, M. Krcmar, and G.S. Painter, Electronic and Structural Origin of Ultraincompressibility of 5d Transition Metal Diborides $\mathrm{MB}_{2}(\mathrm{M}=\mathrm{W}, \mathrm{Re}, \mathrm{Os})$, Phys. Rev. Lett., 2008, 100, p 196403

35. P. Rogl, H. Nowotny, and F. Benesovsky, Über einige Komplexboride mit Platinmetallen, Complex Borides with Platinum Metals, Monatsh. Chem., 1972, 103, p 965-989, in German

36. H. Duschanek and P. Rogl, Critical Assessment and Thermodynamic Calculation of the Binary System Boron-Tungsten, JPE, 1995, 16(2), p 150-161

37. E. Rudy and W. Windisch, The Systems Mo-B and W-B, AFML-TR-2, Part I, Vol. III, Wright Patterson Air Force Base, OH, USA, 1965, p 1-72

38. T.B. Massalski, Binary Alloys Phase Diagrams, 2nd ed., ASM International, Materials Park, Ohio, USA, 1990
39. P. Rogl, Phase Diagrams of Ternary Metal-Boron-Carbon Systems, Ed. Günter Effenberg; ASM International, Materials Park, Ohio 44043 (1988) p 1-566

40. A.J. Crespo, L.-E. Tergenius, and T. Lundström, The Solid Solution of $4 \mathrm{~d}, 5 \mathrm{~d}$ and SOMe p-Elements in ß-Rhombohedral Boron, J. Less Common Met., 1981, 77, p $147-150$

41. M.F. Gabouskas, J.S. Kasper, and G.A. Slack, The Incorporation of Vanadium in $\beta$-Rhombohedral Boron as Determined by Single-Crystal Diffractometry, J. Solid State Chem., 1986, 63, p 424-430

42. I. Smid and P. Rogl, "Phase Equilibria and Structural Chemistry in Ternary Systems: Transition Metal-Boron-Nitrogen", In Science of Hard Materials, Inst. Phys. Conf. Ser. No. 75. Chapter 4, Adam Hilger Ltd., 1986, p 249-257

43. B. Aronsson, E. Stenberg, and J. Åselius, Borides of Rhenium and the Platinum Metals. The Crystal Structure of $\mathrm{Re}_{7} \mathrm{~B}_{3}$, $\mathrm{ReB}_{3}, \mathrm{Rh}_{7} \mathrm{~B}_{3}, \mathrm{RhB}_{1.1}$ (approximate composition), $\mathrm{IrB}_{1.1}$ (approximate composition) and PtB, Acta Chem. Scand., 1960, 14, p 733-741

44. J.B. Levine, S.H. Tolbert, and R.B. Kaner, Advances in the Search for Superhard Ultra-Incompressible Metal Borides, Adv. Funct. Mater, 2009, 19, p 3519-3533

45. P. Rogl and E. Rudy, New Complex Borides with $\mathrm{ReB}_{2}$ and $\mathrm{Mo}_{2} \mathrm{IrB}_{2}$-Type Structure, J. Solid State Chem., 1978, 24(2), p $175-181$

46. T. Lundström, The Structure of $\mathrm{Ru}_{2} \mathrm{~B}_{3}$ and $\mathrm{WB}_{2.0}$ as Determined by Single Crystal Diffractometry, and Some Notes on the W-B System, Arkiv Kemi, 1969, 30, p 115-127

47. R.B. Roof, Jr, and C.P. Kempter, New Orthorhombic Phase in the Ru-B and Os-B Systems, J. Chem. Phys., 1962, 37, p 1473-1476

48. B. Aronsson, The Crystal Structure of $\mathrm{RuB}_{2}, \mathrm{OsB}_{2}$ and $\operatorname{IrB}_{1.35}$ and Some General Comments on the Crystal Chemistry of Borides in the Composition Range MeB-MeB 3 , Acta Chem. Scand., 1963, 17, p 2036-2050

49. J.T. Norton, H. Blumenthal, and S.J. Sindeband, Structure of Diborides of Titanium, Zirconium, Columbium, Tantalum and Vanadium, Trans. Am. Inst. Min. Metall. Pet. Eng., 1949, 185, p 749-751

50. H.P. Klesnar, T.L. Aselage, B. Morosin, G.H. Kwei, and A.C. Lawson, The Diboride Compounds of Molybdenum: $\mathrm{MoB}_{2-x}$ and $\mathrm{Mo}_{2} \mathrm{~B}_{5-y}$, J. Alloys Compd., 1996, 241, p 180-186 